\title{
Two insulin-responsive glucose transporter isoforms and the insulin receptor are developmentally expressed in rabbit preimplantation embryos
}

\author{
Anne Navarrete Santos, Sarah Tonack, Michaela Kirstein, Silke Kietz and Bernd Fischer \\ Department of Anatomy and Cell Biology, Martin Luther University Faculty of Medicine, Grosse Steinstrasse 52, \\ D-06108 Halle (Saale), Germany
}

Correspondence should be addressed to B Fischer; Email: bernd.fischer@medizin.uni-halle.de

\begin{abstract}
Glucose is the most important energy substrate for mammalian blastocysts. Its uptake is mediated by glucose transporters (GLUT). In muscle and adipocyte cells insulin stimulates glucose uptake by activation of the insulin receptor (IR) pathway and translocation of GLUT4. GLUT4 is expressed in bovine preimplantation embryos. A new insulin-responsive isoform, GLUT8, was recently described in mouse blastocysts. Thus, potentially, two insulin-responsive isoforms are expressed in early embryos. The mechanism of insulin action on embryonic cells, however, is still not clear. In the present study expression of IR, GLUT1, 2, 3, 4, 5 and 8 was studied in rabbit preimplantation embryos using RT-PCR, Western blotting and immunohistochemistry. The rabbit mRNA sequences for the complete coding region of IR, GLUT4 and a partial GLUT8 sequence were determined by RACE-PCR and sequencing. GLUT4 was expressed in 3-day-old morulae and in 4- and 6-day-old blastocysts. IR and GLUT8 transcripts were detectable only in blastocysts. Blastocysts also expressed GLUT1 and 3, but not GLUT2 and 5 . Transcript numbers of GLUT4 and 8 were higher in trophoblast than in embryoblast cells. Translation of IR, GLUT4 and 8 proteins in blastocysts was confirmed by Western blotting. GLUT4 was localized mainly in the membrane and in the perinuclear region in trophoblast cells while in embryoblast cells its localization was predominantly in the perinuclear cytoplasm. The possible function(s) of two insulin-responsive isoforms, GLUT4 and GLUT8, in rabbit preimplantation embryos needs further investigation. It may not necessarily be linked to insulin-stimulated glucose transport.

Reproduction (2004) 128 503-516
\end{abstract}

\section{Introduction}

Insulin stimulates cell proliferation and differentiation in preimplantation embryos. Although these embryos do not synthesize insulin (Telford et al. 1990a,b, Kaye 1997, Lighten et al. 1997) they have access to maternal insulin in vivo via oviduct and uterine fluid (Heyner et al. 1989, Chi et al. 2000). The presence of insulin receptors (IR) and insulin growth factor-I (IGF-I) receptors (IGF-IR) in embryos has been described in several species (see Kaye 1997 for review). IR and IGF-IR are expressed in human (Lighten et al. 1997) and bovine (Schultz et al. 1992, Watson et al. 1992, Schultz \& Heyner 1993, Yaseen et al. 2001) oocytes and throughout preimplantation embryo development. In mouse embryos expression starts at the 8-cell stage (Harvey \& Kaye 1988, 1990, Rappolee et al. 1992, Schultz \& Heyner 1993, Markham \& Kaye 2003). Rabbit embryos bind insulin and IGF-I from the morula stage onwards on embryoblast and trophoblast cells.

Insulin binds to its cell surface located receptor. The mature receptor is composed of two extracellular $\alpha$ and two transmembrane $\beta$ subunits which are disulfide-linked to an $\alpha_{2} \beta_{2}$ heterotetrameric structure (Lee \& Pilch 1994, Czech \& Corvera 1999). Following insulin binding to the extracellular $\alpha$-subunit tyrosine kinase domain, the $\beta$ subunits undergo a series of intramolecular transautophosphorylation reactions, resulting in tyrosine autophosphorylation at multiple sites. This activates a series of intracellular signaling cascades which coordinately initiate the appropriate cellular response. Insulin and IGF-I act as a survival factor by decreasing apoptosis and increasing cell proliferation (Herrler et al. 1998, Spanos et al. 2000). Another important mechanism is the increase of glucose transport via the insulin-dependent translocation of the facilitative glucose transporter 4 (GLUT4) from intracellular storage vesicles (Rea \& James 1997) to the plasma membrane in insulin target tissues, primarily striated muscle and adipose tissue (Pessin et al. 1999, Patki et al. 2001). Currently, the GLUT family comprises 13 members, GLUT1-12 and HMIT $\left(\mathrm{H}^{+}\right.$ coupled myo-inositol-transporter) (Joost et al. 2002, Stuart Wood \& Trayhurn 2003). Each GLUT isoform consists 
of 12 helical transmembrane-spanning domains, an extracellular glycosylated hydrophilic segment, an intracellular loop and intracellular located amino- and carboxyl-terminals (Mueckler et al. 1985, Cope et al. 1994).

The expression pattern of glucose transporters in preimplantation embryos has been studied in the mouse (Hogan et al. 1991, Aghayan et al. 1992, Morita et al. 1992, Chi et al. 1993, Pantaleon et al. 1997), rabbit (Robinson et al. 1990), bovine (Lequarre et al. 1997, Wrenzycki et al. 1998, 2003, Navarrete Santos et al. 2000, Augustin et al. 2001) and human (Dan-Goor et al. 1997). In mice, GLUT1 was found in all preimplantation stages. GLUT3 was detected from the eight-cell stage onwards (Pantaleon et al. 1997). While expression of the recently described insulin responsive GLUT8 was shown in mouse blastocysts (Carayannopoulos et al. 2000), the other insulin-sensitive isoform, GLUT4, was not found in mice preimplantation or early postimplantation stages (Hogan et al. 1991, Aghayan et al. 1992). In preimplantation embryos of other species, however, GLUT4 has been detected (bovine: Navarrete Santos et al. 2000, Augustin et al. 2001, rat: Korgun et al. 2001). Therefore, the question arose whether and which compounds of the insulinGLUT signaling cascade are expressed in embryos and which function they may execute during preimplantation development in mammals. Here we show that IR and both insulin-responsive isoforms, GLUT4 and GLUT8, are expressed in rabbit preimplantation embryos in a developmentally regulated manner. Rabbit blastocysts also express GLUT1 and GLUT3, but not GLUT2 and GLUT5.

\section{Materials and Methods}

The TRIzol reagent, Superscript II RT-kit, dNTPs and Taq polymerase were purchased from Invitrogen (Karlsruhe, Germany), restriction enzymes were from New England Biolabs (Frankfurt, Germany), and T7 RNA polymerase, random primer, RNAse inhibitor and DNAse I were from Roche Diagnostics (Mannheim, Germany).

\section{Embryo recovery}

Embryos were collected from sexually mature rabbits (hybrid strain Zika) which had been stimulated by 100 I.U. follicle-stimulating hormone (Ovagen, ImmunoChemical Products, Auckland, New Zealand). Mating, embryo recovery and embryo culture were performed as described before (Kietz \& Fischer 2003). Morulae were flushed on day 3 and blastocysts on days 4 and 6 post coitum; they were washed three times in PBS, pooled and randomly divided among the experimental groups. For molecular analysis embryos were stored until use at $-80^{\circ} \mathrm{C}$ in TRIzol reagent and in RIPA buffer for RNA and protein isolation respectively.

In order to investigate spatial expression of GLUT4 and GLUT8 in trophoblast (TE) and embryoblast cells (inner cell mass, ICM), blastocyst coverings were mechanically removed and the embryonic disks were microdissected from the trophoblast under a stereomicroscope. Isolated ICM and TE from each blastocyst (total number 11 blastocysts) were stored separately at $-80^{\circ} \mathrm{C}$. For immunohistochemistry embryos were fixed overnight in Bouin fixative containing 75\% (v:v) aqueous-saturated picric acid solution, 20\% (v:v) formalin, and 5\% (v:v) acetic acid and/or in $4 \%(\mathrm{v}: \mathrm{v})$ paraformaldehyde/PBS overnight. Bouin-fixed embryos were dehydrated and embedded in paraffin. Sections $(5 \mu \mathrm{m})$ were prepared with an ultramicrotome. Paraformaldehyde-fixed embryos were dehydrated and stored in methanol at $-20^{\circ} \mathrm{C}$ until whole mount staining.

\section{RNA extraction}

Preparation of total RNA from whole embryos was performed by using $1 \mathrm{ml}$ TRIzol reagent according to the previously described protocol (Koerber et al. 1998). Total RNA from tissues was extracted as described by Chomczynski and Sacchi (1987). RNA was treated with DNAse for $1 \mathrm{~h}$. The amount of total RNA was determined spectrophotometrically at $260 \mathrm{~nm}$. The mRNA extraction from separated trophoblast and embryoblast was performed with DYNABEADS (Dynal, Oslo, Norway) in order to collect sufficient amounts from the small number of cells.

\section{Cloning of rabbit IR, GLUT4 and GLUT8 sequences}

Rabbit IR, GLUT4 and GLUT8 cDNA sequences were determined by PCR amplification with degenerated primers derived from human sequences (IR accession no. (acc.) X02160.1, GLUT4 acc. M91463, GLUT8 acc. Y17801, primers shown in Table 1) and 3' RACE-PCR (3/5 RACE kit, Roche Diagnostics) using specific rabbit primers (Table 1) on reverse transcribed rabbit skeletal muscle and liver mRNA for GLUT4 and IR, and GLUT8 respectively. The amplified PCR products were purified by separation in a preparative $1.8 \%$ agarose gel and extracted by a Gel Extraction kit (Qiagen, Hilden, Germany) following the manufacturer's protocol. Fragments were cloned into the pGEM-T vector and transformed into competent E. coli XL1blue cells. Recombinant plasmid DNA was analyzed by restriction analysis and sequenced using the $A B I$ Prism Ready Reaction Dyedeoxy Terminator Sequencing kit (Amersham Biotech, Freiburg, Germany) and T3 and T7 sequencing primers in an $\mathrm{ABI} 373$ automated sequencer. The sequenced cDNA was screened for homology in the GenBank EMBL using the BLASTN search modus and for amino acids using the BLASTP search modus.

\section{Sequence alignment}

Sequence alignment of rabbit IR and GLUT4 protein sequences was performed by CLUSTAL W (1.82) multiple sequence alignment.

\section{RT-PCR of IR, GLUT1-5 and 8 mRNA}

Primers used for RT-PCR are listed in Table 1. One microgram total RNA was reverse transcribed in a volume of 
Table 1 Specific rabbit (rab) and human (hu) primers used for RT-PCR analysis, RACE-PCR and sequencing.

\begin{tabular}{|c|c|c|}
\hline Gene & Name & $5^{\prime}$-Sequence-3' \\
\hline \multirow[t]{2}{*}{ GLUT1 } & rabGLUT1 p1 & GCTGATGATGAACCTGCTGG \\
\hline & rabGLUT1 p2 & GGTTGATGAGCAGGAAGCG \\
\hline \multirow[t]{2}{*}{ GLUT2 } & rabGLUT2 p1 & САGСТСТTTACСАACTCCAG \\
\hline & rabGLUT2 p2 & GCTCACATAACTCATCCAGG \\
\hline \multirow[t]{2}{*}{ GLUT3 } & rabGLUT3 p1 & TCTGGAAATCATCTTGGGGTTCT \\
\hline & rabGLUT3 p2 & CCGTAGAGTAATAGAACACAGC \\
\hline \multirow[t]{7}{*}{ GLUT4 } & rabGLUT4 p1 & GGCGGCATGATTTCCTCC \\
\hline & rabGLUT4 p2 & GAAGGGCAGCAGGATCAGCT \\
\hline & rabGLUT4 p3 & GGTGCTCССТGСССТССT \\
\hline & rabGLUT4 p4 & ATCGСССТСТTССТTСССА \\
\hline & huGLUT4 p1 & GAAGGTGATTGAACAGAGC \\
\hline & huGLUT4 p2 & GATGATGTAGAGGTAGCG \\
\hline & huGLUT4 p3 & ATGCCGTCGGGCTTCCAAC \\
\hline \multirow[t]{2}{*}{ GLUT5 } & rabGLUT5 p1 & GCAGCAAAGTCGCCAGGTCG \\
\hline & rabGLUT5 p2 & GTAGATGGCGTTCACTCCCGA \\
\hline \multirow[t]{4}{*}{ GLUT8 } & rabGLUT8 p1 & CACGTCAAGGGTGTGGCT \\
\hline & rabGLUT8 p2 & CAGGGACGCAGAACAAAGTG \\
\hline & huGLUT8 p1 & GCTCСTCATGTCAGAGATCT \\
\hline & huGLUT8 p2 & TCCССTTGGTTTCAGGGAC \\
\hline \multirow[t]{11}{*}{ Insulin receptor } & rablnsR p1 & GCTGGTGGTGATGGAGTTG \\
\hline & rablnsR p2 & TCTCTCTGGACAGTTGTCGG \\
\hline & rablnsR p3 & AGATCTCATGCGTCACGGG \\
\hline & rablnsR p4 & AGCAGGTGTTGAAGTTTGTC \\
\hline & rablnsR p5 & AGAGGCCTCGGAAGTCGG \\
\hline & hu InsR p1 & GGACCATGCCTGAAGCCAAG \\
\hline & hu InsR p2 & TGAATTGCCAGCACATGCG \\
\hline & hu InsR p7 & СTGAGATGGAGACCGTACTG \\
\hline & hu InsR p8 & TTAGGAAGGATTGGACCGAG \\
\hline & hu InsR p9 & ATCGACTGGTCCCGTATCC \\
\hline & hu InsR p12 & CACCTGTACCCCGGAGAG \\
\hline \multirow[t]{2}{*}{ Cytokeratin 18} & rabCytoker p1 & CAGATTGAGGAGAGCACCAC \\
\hline & rabCytoker p2 & AGTCCTCGCCATCTTCCAGC \\
\hline \multirow{2}{*}{$\beta$-actin } & rabActin p1 & CTACAATGAGCTGCGTGTGG \\
\hline & rabActin p2 & TAGCTCTTCTCCAGG GAGGA \\
\hline
\end{tabular}

$20 \mu \mathrm{l}$ containing $0.5 \mathrm{mM}$ dNTPs, $10 \mathrm{mM}$ dithiothreitol (DTT), 200 units superscript II, 20 units RNAse inhibitor, $1 \mu \mathrm{l}$ random primer and $2 \mu \mathrm{l}$ reverse transcriptase buffer at $42{ }^{\circ} \mathrm{C}$ for $1 \mathrm{~h}$, followed by an incubation at $90^{\circ} \mathrm{C}$ for 5 min. As a control for DNA contamination, $1 \mu \mathrm{g}$ RNA was PCR amplified without reverse transcription reaction. This control reaction was performed for each primer combination and in all PCR amplifications. PCR amplification was carried out with $1 \mu \mathrm{l}$ CDNA in a $50 \mu \mathrm{l}$ volume containing $5 \mu \mathrm{l}$ dNTP, 2.5 units Taq polymerase, employing the primer combinations listed in Table 1. Resulting PCR products were separated by electrophoresis on 1.8\% agarose gel and stained with ethidium bromide.

\section{Semiquantitative RT-PCR on the separated trophoblast and embryoblast tissue}

Trophoblast and embryoblast mRNA were directly transcribed into cDNA with the RNA-PCR Core kit (PerkinElmer Roche, Boston, USA). Reverse transcription reaction was performed in a thermocycler (Biometra, Göttingen, Germany) under the following conditions: $10 \mathrm{~min}$ at $25^{\circ} \mathrm{C}, 1 \mathrm{~h}$ at $42^{\circ} \mathrm{C}, 5 \mathrm{~min}$ at $99^{\circ} \mathrm{C}$. Afterwards $40 \mu \mathrm{l} \mathrm{H}_{2} \mathrm{O}$ were added. The quality of tissue separation was controlled by cytokeratin 18 PCR (see Fig. 5A). Only embryos with clearly higher transcript numbers of cytokeratin 18 in the separated trophoblast and low expression in embryoblast tissues were used for semiquantitative PCR on GLUTs. To equalize for different RNA amounts of individual embryos, first a PCR on $\beta$-actin was performed. This housekeeping gene was used as an internal standard for GLUT transcript numbers (Kietz \& Fischer 2003). All PCR reactions were carried out in $50 \mu$ l volume containing $2 \mu \mathrm{l}$ cDNA, $1.5 \mathrm{mM} \mathrm{MgCl}_{2}, 0.2 \mathrm{mM}$ dNTPs, $1 \mathrm{U}$ Taq polymerase (Life Technologies, Eggenstein, Germany) and $150 \mathrm{ng}$ of the primer combination, rabActinp1/p2 and rabGLUT1p1/p2, rabGLUT3p1/p2, rabGLUT4p1/p2 and rabGLUT8p1/p2 (Table 1) for GLUT1, GLUT3, GLUT4 and GLUT8 respectively. The amplification profile was as follows: $5 \mathrm{~min}$ at $94^{\circ} \mathrm{C}, 28$ ( $\beta$-actin), 32 (GLUT1, GLUT3, GLUT8) and 35 (GLUT4, cytokeratin 18) cycles of $1 \mathrm{~min}$ at $94{ }^{\circ} \mathrm{C}, 1 \mathrm{~min}$ at $60^{\circ} \mathrm{C}, 1 \mathrm{~min}$ at $72{ }^{\circ} \mathrm{C}$, and a final extension period for $5 \mathrm{~min}$ at $72^{\circ} \mathrm{C}$. Gels were photographed and the product bands were quantified by densitometric analysis employing the software BIO-Profile 1D (LTFLabortechnik, Wasserburg, Germany). The relative amount of GLUT1, GLUT3, GLUT4 and GLUT8 mRNA was calculated as a ratio of the specific product and the housekeeping gene band volume ( $\beta$-actin). All PCR reactions were performed three times.

The statistical analysis was performed using paired $t$-test (SigmaPlot 4.0, Jandel Corporation (San Rafael, CA, USA), mathematical and statistical analysis). The data are expressed as means \pm S.E.M.

\section{Protein preparation and immunoblotting}

Blastocysts were washed three times with PBS after culture and transferred to a $1.5 \mathrm{ml}$ Eppendorf tube. They were homogenized in $100 \mu$ l cold RIPA buffer (PBS, 1\% NP-40, $0.5 \%$ sodium deoxycholate, $0.1 \%$ sodium dodecyl sulfate (SDS)) with a protease inhibitor cocktail (Sigma, St Louis, $\mathrm{MO}$, USA). The samples were centrifuged at $5000 \mathrm{~g}$ for $10 \mathrm{~min}$. The supernatant was stored at $-80^{\circ} \mathrm{C}$ until use. The total protein content was determined using the BIORAD Protein Assay (Bio-RAD, München, Germany). Twenty micrograms embryonic protein and $40 \mu \mathrm{g}$ of reference tissues were heated at $70^{\circ} \mathrm{C}$ for $5 \mathrm{~min}$ before solubilizing in Laemmli buffer containing $200 \mathrm{mM}$ DTT and electrophoresed on 8\% SDS-PAGE. Proteins were electrotransferred to nitrocellulose membranes. Membranes were blocked for $1 \mathrm{~h}$ in Tris-buffered saline containing $0.1 \%$ Triton (TBST) with 5\% BSA (for detection of IR) or $5 \%$ non-fatty milk powder (for GLUT4 and GLUT8) at room temperature. Blots were incubated in TBST containing 5\% BSA with monoclonal mouse anti-IR ( $\beta$-subunit, Ab-4, Oncogene Research Products Calbiochem, Darmstadt, Germany) at a dilution of $1: 200$, in 5\% nonfat milk powder/TBST with monoclonal mouse anti-GLUT4 antibody (1:6000, DPC Biermann, Bad Nauenheim, Germany) or rabbit anti-GLUT8 antibody (1:400, Alpha Diagnostics International, San Antonio, TX, USA) overnight at $4{ }^{\circ} \mathrm{C}$. 
Blots were subjected to three 20-min washes in TBST and incubated for $1 \mathrm{~h}$ with goat anti-mouse IgG (1:25000) or goat anti-rabbit $\operatorname{lgG}(1: 20000)$ conjugated to horseradish peroxidase (Dianova, Hamburg, Germany) in 5\% BSA/TBST or $5 \%$ non-fatty milk powder/TBST at room temperature. Afterwards, the immunoreactive signals were visualized by enhanced chemiluminescence detection (ECL Plus, Amersham Biotech). Apparent molecular weights were determined by comparison with standard molecular weight markers (high range marker, Promega Corp., Mannheim, Germany).

\section{Immunohistochemistry (IHC)}

The GLUT4 antigen was localized on embryonic sections and whole blastocysts. Bouin-fixed, paraffin-embedded

A)

hUGLUT4P3

ATGCCGTCGGGCTTCCAACAGATCGGCTCCGAAGATGGGGAACCCCCCCAGCAGCGGGTCACCGGAACCCTGGTCCTCGCCGTGTTCTCA 90

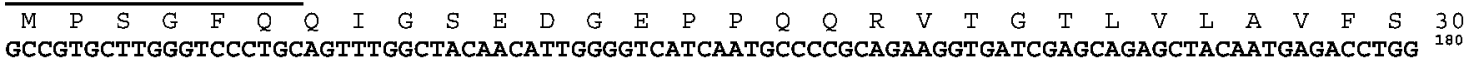

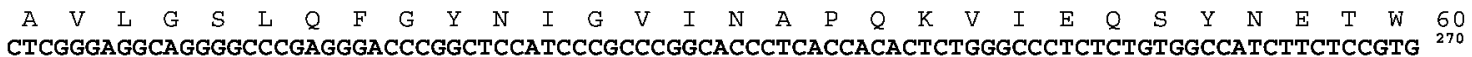

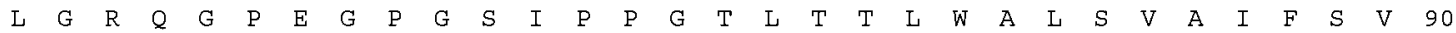
$r a b G L U T 4 p 1 \rightarrow$

GGCGGCATGATTTCCTCCTTCCTCATCGGCATCATCTCCCAGTGGCTGGGAAGGAAGAGGGCGATGCTGGCCAACAACGTCCTGGCCGTG 360

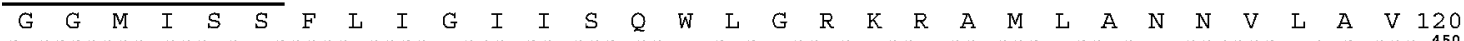
CTGGGGGGCACCCTCATGGGCCTGGCCAACGCTGCTGCCTCCTATGAGATGCTCATCCTTGGACGGTTCCTCATTGGCGCCTACTCAGGG 45

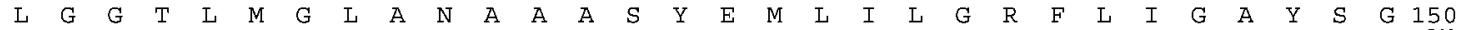
CTGACATCAGGGCTTGTGCCCATGTACGTGGGGGAGATTGCCCCCACTCACCTGCGAGGTGCCTTGGGGACGCTCAACCAGCTGGCCATC 540

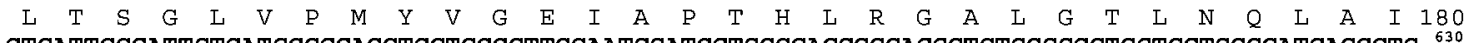
GTCATTGGCATTCTGATCGCCCAGGTGCTGGGCTTGGAATCCATGCTGGGCACCGCCACCCTGTGGCCGCTGCTCCTGGGCATCACGGTG ${ }^{630}$

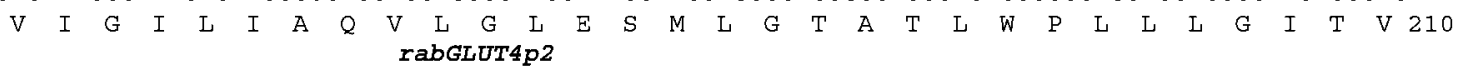

CTCCCTGCCCTCCTGCAGCTGATCCTGCTGCCCTTCTGCCCCGAGAGCCCCCGCTATCTCTACATCATCCGGAACCTGGAGGGGCCGGCC ${ }^{20}$

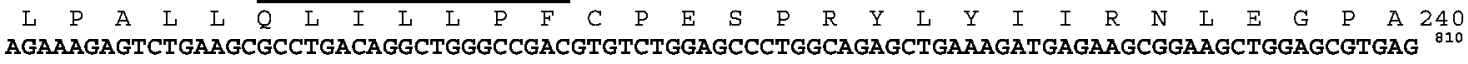
$\begin{array}{llllllllllllllllllllllllllllllllllllll}R & K & S & L & K & R & L & T & G & W & A & D & V & S & G & A & L & A & E & L & K & D & E & K & R & K & L & E & R & E & 270\end{array}$ CGGCCACTGTCCCTGCCCCAACTCCTGGGCAGCCGCACCCACCGGCAGCCCCTCATCATTGCCGTGGTGCTGCAGCTGAGCCAGCAGCTC ${ }^{900}$

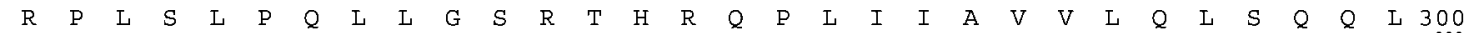
TCAGGCATCAATGCTGTTTCTATTATTCGACCAGCATCTTCGAGACAGCAGGGGTAGGGCAGCCCGCCTATGCCACCATAGGAGCTGGA 990 $\begin{array}{llllllllllllllllllllllllllllllllllll}S & G & I & N & A & V & F & Y & Y & S & T & S & I & F & E & T & A & G & V & G & Q & P & A & Y & A & T & I & G & A & G & 330\end{array}$ GTGGTCAACACAGTGTTCACCCTGGTCTCGGTGTTCTTGGTGGAACGGGCTGGGCGCCGGACACTCCACCTCCTGGGCCTGGCGGGCATG ${ }^{1080}$

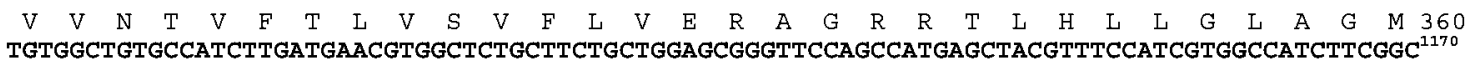

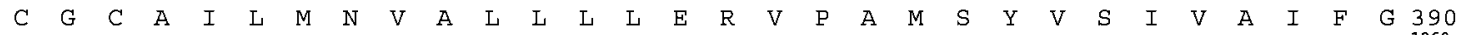
TTTGTGGCGTTCTTTGAGATCGGCCCTGGCCCCATCCCCTGGTTCATCGTGGCCGAGCTCTTCAGCCAGGGGCCCCGCCCTGCAGCCATG ${ }^{1260}$

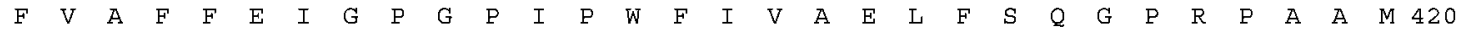
GCTGTGGCTGGGTTCTCCAACTGGACGTGCAACTTCATCATCGGCATGGGATTCCAGTACGTTGCGGATGCAATGGGGCCCTACGTCTTC ${ }^{1350}$

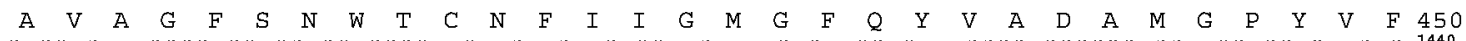
СTCСTCTTTGCCGTCСTCСTGCTGGGCTTCTTCATCTTCACСTTCTTAAGAGTACCTGAAACCCGAGGCCGGACCTTCGACCAGATCTCA 1440 $\begin{array}{lllllllllllllllllllllllllllllllllllll}\mathrm{L} & \mathrm{L} & \mathrm{F} & \mathrm{A} & \mathrm{V} & \mathrm{L} & \mathrm{L} & \mathrm{L} & \mathrm{G} & \mathrm{F} & \mathrm{F} & \mathrm{I} & \mathrm{F} & \mathrm{T} & \mathrm{F} & \mathrm{L} & \mathrm{R} & \mathrm{V} & \mathrm{P} & \mathrm{E} & \mathrm{T} & \mathrm{R} & \mathrm{G} & \mathrm{R} & \mathrm{T} & \mathrm{F} & \mathrm{D} & \mathrm{Q} & \mathrm{I} & \mathrm{S} & 480\end{array}$ GCTGCCTTCCGCCGGACGCCGTCTCTCTTAGAGCAGGAGGTGAAGCCCAGCACGGAACTTGAGTACTTGGGGCCAGATGAGAATGACTGA 1530

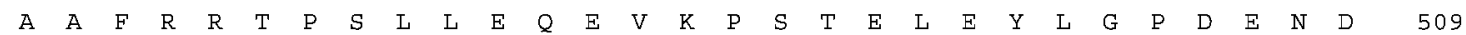
GCCAGGCAGGGGTGGGGGGAACCCGCCCTCCCCGCCCACCGGGACCCTCCTTTCCTCCGCAGCACTTTAACCCCCTCCTCCCGGTTCCTG ${ }^{1620}$ CCAGGGCGGACAGACTTCCCCTGCAGCCTGGTGGACCTGGGAGGCAGGAGGGAAGGGGCAGTCTGAGCGCCCCTCATTCCCCTCGCGTGA ${ }^{1710}$ CTCTTGGGTTATTTATGTGTGTGGTTAGGCTGTGGCCAGCAGCGTGGCCCACTCTCCCCTCCTGTCTTCCTCCCTAGCCCAGCCCCTTCC ${ }^{1800}$ TGCCCACCCCCTACCCCTCCCCGACCCTGCCTTCTGGCTAGAGAAGAGGGATTGGAGGGAGTGGGACAAACTGAGGCGGAGAGCAGCTGG ${ }^{1990}$ GGAGCAGAAGTCACGTTCCCCACCGGCCGCCAGCGGGCACTTTCACTGGATTCTTGCCACATGGACTCCGGGTGAAGGGAGTTCTGTCTC ${ }^{1980}$ AGCCCTCCAGGGCAAAGGATGCACCCTTGCTTCTCACTGCAGGCTCAGCCTCGCGGGGCGAGAGGGAATGCGAAAGCACATGCCCATATG ${ }^{2070}$ TGGCGAGAGGAAGGGGCCCTACCCCGGTTGCTCGCCAAGGCTGCCAAGTGGGGGCTCCGGCGCTGTCCTCTGCTCCCCTCCTGGAAGGGT ${ }^{2160}$ GCTGCACCCACAGGCTCTTGACCAACTAGGGAAAGGGGTTGGAAAGGCTGCCCGTGAACACTGGGCTAGGAGGAGCCGTCAGATATTTTT 2250 GTATATATTTGAAGAAGGGGTAGGGAGGAGCAGCCAAGGTCTGCTGTACTAAATGTGTCTATAGAGCTGCTTCTATAAAGTGACTGTATA 2340 AAAAAAAAAAAAAAA 2355

B)

rabGlut $8 p 1$

GCTCCTCATGTCAGAGATCTTCCCGCTGCACGTCAAGGGTGTGGCTACGGGCGTCTGCGTCCTCACCAACTGGCTCATGGCCTTCCTAGT 90

$\begin{array}{lllllllllllllllllllllllllllllllll}\mathrm{L} & \mathrm{L} & \mathrm{M} & \mathrm{S} & \mathrm{E} & \mathrm{I} & \mathrm{F} & \mathrm{P} & \mathrm{L} & \mathrm{H} & \mathrm{V} & \mathrm{K} & \mathrm{G} & \mathrm{V} & \mathrm{A} & \mathrm{T} & \mathrm{G} & \mathrm{V} & \mathrm{C} & \mathrm{V} & \mathrm{L} & \mathrm{T} & \mathrm{N} & \mathrm{W} & \mathrm{L} & \mathrm{M} & \mathrm{A} & \mathrm{F} & \mathrm{L} & \mathrm{V} & 30\end{array}$

GACCAAGGAGTTCAGCAGCGTCATGGAGGCCCTCCGGCCCTACGGCGCGTTCTGGCTCGCCTCTGCCTTCTGCATCTTCGGCGTCCTTTT 180

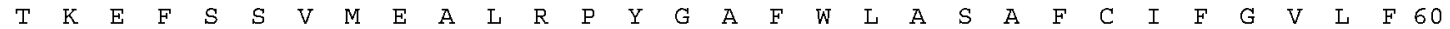

$\rightarrow$ rabGlut $8 p 2$

CACTTTGTTCTGCGTCCCTGAAACCAAGGGGAAGACTCTGGAACAAATCACAGCC 235

\begin{tabular}{llllllllllllllllllllllllll}
\hline T & $L$ & $F$ & $C$ & $V$ & $P$ & $E$ & $T$ & $K$ & $G$ & $K$ & $T$ & $L$ & $E$ & $Q$ & $I$ & $T$ & $A$ & 70
\end{tabular}

Figure 1 Continued. 
C)

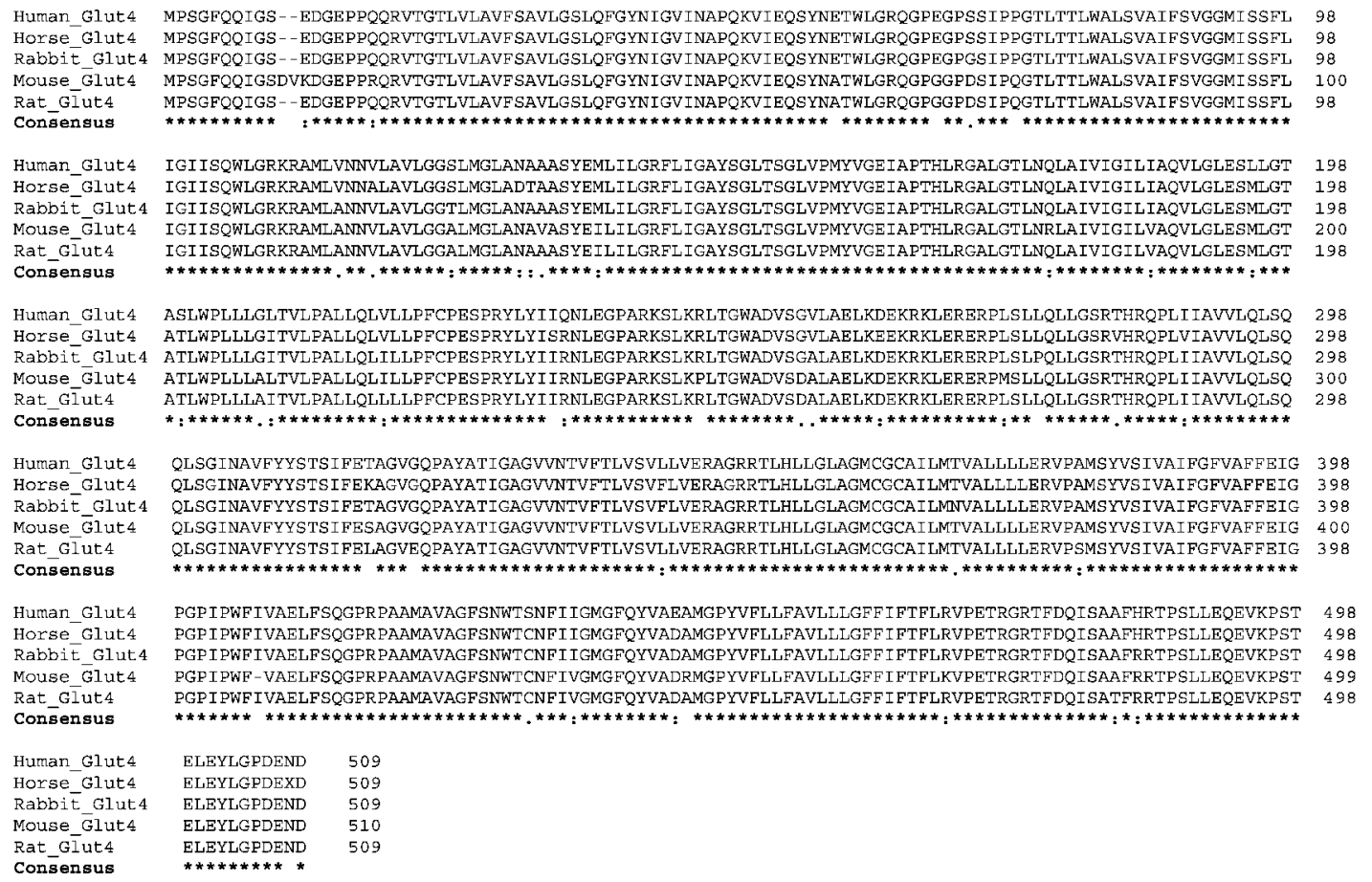

Figure 1 Rabbit GLUT4 (A) and GLUT8 (B) CDNA and the predicted protein sequences. The localizations of the specific rabbit PCR primers (rabGLUT4p1 and rabGLUT4p2) used in this study are underlined. The single open reading frame is translated into a 509 amino acid protein (A). Interspecies comparisons of the GLUT4 protein sequences (C) show that the rabbit GLUT4 is a member of the GLUT family. The multiple sequence alignments of GLUT4 protein for mouse (accession number AB008453), rat (accession number D28561), rabbit, human (accession number M20747) and horse (accession number AF531753) were performed by CLUSTAL W (1.82) multiple sequence alignment. The consensus is displayed by the following symbols denoting the degree of conservation observed in each column: $(*)$ means that the residues or nucleotides in that column are identical in all sequences in the alignment, (:) means that conserved substitutions have been observed, (.) means that semiconserved substitutions have occurred.

day 6 rabbit blastocysts were sectioned at $5 \mu \mathrm{m}$. Sections were mounted on silanized slides, deparaffinized in xylene and rehydrated through a series of graded alcohols. Various antigen retrieval methods were tested on the paraffin-embedded rabbit tissues for IR antigen detection. With the monoclonal mouse anti-IR ( $\beta$-subunit, Ab-4, Oncogene Research Products Calbiochem) we could not detect any immunoreactions on fixed tissues (rabbit liver, muscle) or embryo sections. For whole mount-IHC the paraformaldehyde-fixed blastocysts were rehydrated through a series of graded alcohols. The neozona was removed mechanically before peroxidase blocking. Endogenous peroxidase was quenched by treatment with $3 \%$ hydrogen peroxide in methanol for $30 \mathrm{~min}$. Non-specific antibody binding was blocked with $10 \%$ normal goat or donkey serum in PBS at room temperature for $1 \mathrm{~h}$ and incubated with the primary antisera overnight at $4{ }^{\circ} \mathrm{C}$ in a humidified chamber. GLUT4 antibody (mouse anti-GLUT4 antibody $1: 2500$, DPC Biermann) was diluted in PBS with $1 \%$ BSA. Sections and whole blastocysts were rinsed with PBST and incubated with the peroxidase-labeled secondary antisera (DAKO EnVision +/HRP-goat-anti mouse IgG, DAKO, Hamburg, Germany) for conventional light microscopy. The antigen was visualized with the diaminobenzidine (DAB, WAK-Chemie Medikal, Bad Soden, Germany) substrate. The development of DAB was stopped in water after $5 \mathrm{~min}$. Sections were counterstained with hematoxylin, dehydrated and cleared in xylene. The slides were mounted in DPX and examined under brightfield microscopy with an AH-3 microscope (Olympus, Hamburg, Germany). For whole mount confocal microscopy the GLUT4 protein was localized by immunofluorescence detection with the secondary antibody fluorescein (FITC)-conjugated AffinPure donkey-anti-mouse IgG (1:300, Jackson ImmunoResearch Lab. Ltd, Cambridgeshire, UK). The nuclei were counterstained with 7amino-actinomycin. Whole blastocysts were scanned and examined by confocal laser microscopy with Leica TCS SP (Bensheim, Germany). The specificity of immunostaining was demonstrated by the absence of signals in sections and whole embryos incubated with control mouse IgG (DAKO) or in sections processed after omission of the primary antibody. Only reactions with negative controls were included in the study. At least 5 embryos, pooled from different donor animals, were examined per group. 
IHC reactions of the same specimens were repeated three times.

\section{Accession numbers}

The GeneBank accession numbers for rabIR, rabGLUT2, rabGLUT4 and rabGLUT8 were AY339877, CB814983, AY339876 and BF146289 respectively.

\section{Results}

\section{Cloning and sequencing of rabbit GLUT4, GLUT8 and IR $\boldsymbol{m R N A}$}

The rabbit GLUT4 and IR cDNA obtained by RACE-PCR were $2355 \mathrm{bp}$ and $4026 \mathrm{bp}$ long respectively, covering the complete coding region (Figs 1A, 2A). The partial rabbit GLUT8 cDNA sequence with a length of $230 \mathrm{bp}$ (Fig. 1B, rabGLUT8 - accession number BF146289) was amplified from rabbit liver tissues. All sequences show a high homology to human and other mammalian sequences at both the DNA and protein level (Table 2).

The new rabbit cDNA rabGLUT4 (accession number AY339876) belongs to the facilitative glucose transporter family and is closely related to mammalian GLUT4 (Fig. 1C). The GLUT4 5' coding region and the putative start of translation were amplified by human huGLUT4p3 and rabGLUT4p4, whereas the $3^{\prime}$ terminus was determined by $3^{\prime}$-RACE with specific rabGLUT4p3 and a poly $(\mathrm{A})$ specific anchor primer (primers listed in Table 1). The resulting cDNA contains an open reading frame of 1527 nucleotides encoding a protein of 509 amino acids (aa) with a calculated molecular mass of $54.84 \mathrm{kDa}$ and an estimated pl of 7.77. The TGA stop codon is followed by 825 bases of $3^{\prime}$ non-coding region. The rabGLUT4 3'flanking region shows partial homology with the horse, bovine, mouse and human GLUT4 genes and is specific for rabGLUT4. The specific rabbit primers rabGLUT4p1 and rabGLUT4p2 (Table 2, Fig. 1A) were designed for PCR amplification on rabbit embryos yielding a PCR product of $398 \mathrm{bp}$. The primer design avoided genomic amplification due to two bridged introns.

The new rabbit IR cDNA (accession number AY339877) sequence contains the complete region for the $\alpha$ - and $\beta$-subunits of the receptor (Fig. 2). The insulin receptor sequence is highly conserved in mammalian species (Fig. 2). The insulin binding region and the amino acids phosphorylated by tyrosine kinase are identical in the rabbit and human sequences. The complete coding region was cloned. Analysis of a $4026 \mathrm{bp}$ cDNA revealed an open reading frame coding for a propolypeptide of 1341 aa with a molecular mass of $152.4 \mathrm{kDa}$. The protein sequence between rabbit and human IR differed only in 44 aa. In the $\alpha$-subunit the amino acids involved in insulin binding are present. In the $\beta$-subunit the tyrosine residues representing the autophosphorylation consensus sequence were identical to the human ones (Ottensmeyer et al. 2000) (Fig. 2). These molecular features prove that the rabIR gene product is a member of the IR family and represents the insulin receptor from Oryctolagus cuniculus. The identity of the rabbit IR to the receptor molecule is higher than with other members of the IR family such as IGF-IR.

\section{Expression of GLUT isoforms and IR in rabbit embryos}

The glucose transporter isoforms 1, 3, 4, 8 and IR are expressed in expanded rabbit blastocysts (day 6) (Figs 3 and 4). While transcripts of the GLUT4 gene were detectable in rabbit morulae and blastocysts, IR and GLUT8 were not found at the morula stage. First transcripts for IR and GLUT8 mRNA were detectable in early blastocysts recovered on day 3 and in day 4 blastocysts respectively (Fig. 4A). GLUT4 and 8 transcript numbers were significantly higher in the trophoblast than in the embryoblast $(P<0.05)$. Such cell lineage-specific effects were not found for GLUT1 and 3 (Fig. 5B). The GLUT isoforms 2 and 5 were not found in day 6 blastocysts (Fig. 3, rabGLUT2 - accession number CB814983).

Translation of rabGLUT4, GLUT8 and rabIR protein was shown by Western blotting in day 6 blastocysts with bands of the expected molecular weights (Fig. 4B, C, D). Molecular weight and signal specificity of the antibody were verified by employing target tissues such as rabbit heart muscle for GLUT4, GLUT8 and liver for IR in the same blot (Fig. 4B, C, D). GLUT4 immunoreactivity was confirmed by IHC on day 6 blastocysts (Fig. 6). Antibodies for GLUT8 and IR, however, were not immunoreactive on rabbit embryo and target tissues (liver, heart muscle).

\section{Localization of GLUT4}

GLUT4 protein was localized in both the embryoblast and trophoblast of day 6 blastocysts (Fig. 6). Immunohistochemical staining revealed a different subcellular localization of the protein. Whereas the outer trophoblast layer showed a membrane and perinuclear staining, the extraembryonic endoderm exhibited an intense staining for cytoplasmic and perinuclear compartments. Confocal laser scans showed a closed localization of GLUT4 with nuclear membranes in the extraembryonic endoderm. In embryoblast cells, GLUT4 was localized mainly perinuclearly in the cytoplasm.

\section{Discussion}

IR and GLUT4 expression has been reported in various insulin-sensitive tissues of eukaryotic organisms. The present study is the first report on the simultaneous expression of IR, GLUT4 and GLUT8 in preimplantation embryos. All three genes are expressed in rabbit blastocysts. The presence of small amounts of IR and GLUT8 mRNA at the morula stage cannot be excluded. However, the sensitive RT-PCR approach used in this study, based on specific primers for transcript detection, was negative. Due to the lack of appropriate antibodies, we could not verify translation of all three genes into protein. It is 
Rabbit_INSR Human_INSR Mouse_INSR Rat_INSR

Rabbit_INSR Human_INSR Mouse INSR Rat_IN $\bar{N} S R$ Consensus

Rabbit_InSR Human_INSR Mouse_INSR Rat_INSR Consensus

Rabbit_INSR HUman_INSR Mouse_INSR Rat_INSR Cons̄ensus

Rabbit_INSR Human_INSR Mouse_INSR Mouse INSR
Rat INSR Consensu

Rabbit_INSR Human_INSR
Mouse INSR Mat INSR Consensus

Rabbit_INSR Human_INSR Mouse_INS Rat_IN $S R$ Consensus

Rabbit_INSR Human_INSR Mouse_INSR Rat_INSR Consensus

Rabbit_INSR Human_INSR Mouse_INSR Rat_INTSR Consensus

Rabbit INSR Humar_INSR Mouse_INSR Rat_INTS. Consensus

Rabbit__INSR HUman INSR Mouse_INSR Rat_INSR Rat INSR

Rabbit INSR Human_INSR Mouse_INSR Rat_INSR Consensus

Rabbit_INSP Human_INSR Mouse_INSR Rat_IN $\overline{N S R}$ Consengus

Rabbit_INSR Human_INSR Mouse_INS Rat_INNSR Consensus

Signal peptide

M - - HLYPGEVCPGMDIRNNLTRLHELENCSVI EGHLQILLMFKTRPEDFRDLSFPKLIMITDYLLLFRVYGLESLK 73 MGTGGRRAAAAAPLLVAVAALLLGAAGH Y PGEVCPGMDIRNNLTRLHELENCSVI EGHLOILLMFKTRPEDERDLSFPKLIMITDYLLLFRVYGLESLK 100 MGSGRGCETTAVPLLMAVAVAGG - TAGHLYPGEVCPGMDIRNNITRLHELENCSVI EGHLQILLMFKTRPEDFRDLSFPKL IMITDYLLLFRVYGLESLK 99

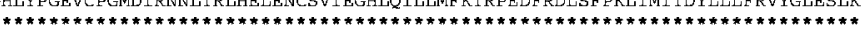

DLF'PNLTVIRGSRLFFNYALVIFEMVHLKEVGLHSLMNITRGSVR I EKNNELCYLATI IDWSRILDSVEDNY IVLNKDDNEECGDICPGTAKGKTNCPATV 173 DLFFNLTVIRGSRLFFNYALVI FEMVHLKELGL YNIMNI TRGSVRIEKMNELCYLATIDWSRILDSVEDNY IVLNKDDNEECGDICPGTAKGKTNCPATV 200 DLFFNLTVIRGSFLFFNYALVIFEMVHLKELGLYNLMNITRGSVR I EKNNELCYLATIDWSRILDSVEDNY IVLNKDDNEECGDVCPGTAKGKTNCPATV 200 DLFPNLTVIRGSRLFFNYALVIFEMVHLKELGLYNLMNI TRGSVRIEKNNELCYLATIDWSRILDYVEDNY IVLNKDDNEECGDVCPGTAKGKTNCPATV 199

INGQFVERCWTHSHCQKVCPT ICKSHGCTAEGLCCHSECLGNCSEPDDPTKCTVCRNFYLDGRCVETCPPPYYHFQDWRCVNFSFCQDLHNKCKNINRRQG 273 INGQEVERCWTHSHCQKVCPT ICKSHGCTAEGLCCHSECLGNCSQPDDPTKCVACRNFYLDGRCVETCPPPYYHFQDWRCVNFSFCQDLHHKCKNSRRQG 300 INGQFVERCWTHSHCOKVCPT ICKSHGCTAEGLCCHKECLGNCSEPDDPTKCVACRNFYLDGOCVETCPPPYYHFODWRCVNFSFCODLHFRCRNSRKPG 300 INGQEVERCWTHSHCQKVCPT ICKSHGCTAEGLCCHKECLGNCSEPDDPTKCVACRNFYLDGQCVETCPPPYYHFQDWRCVNFSFCQDLHYKCRNSRKPG 299

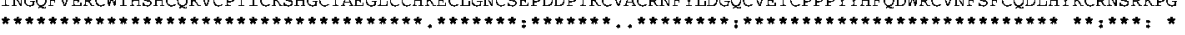

CHQYVIHNNKCIPECPSGYTMNSSNLMCTPCIGPCPKVCHLLDGEKTIDSVTSAQEFRGCTVINGSLIINIRGGNNLA_AELEANFGFIEEISGYLKIRRS 373 CHQYVIHNNKCIPECPSGYTMNSSNLLCTPCLGPCPKVCHLLEGEKTIDSVTSAQELRGCTVINGSLI INIRGGNNLAAELEANLGLIEEISGYLKIRRS 400 CHQYVIHNNKCI PECPSGYTMNSSNLMCTPCLGPCPKVCQI LEGEKT IDSVTSAQELRGCTVINGSLI INI RGGNNLAAELEANLGLIEEISGFLKIRRS 400 CHOYVIHNNKCIPECPSGYTMNSSNLMCTPCLGPCPKVCOILEGEKTIDSVTSAQELRGCTVINGSLI INIRGGNNLAAELEÄLLGIEEISGFLKIRRS 299

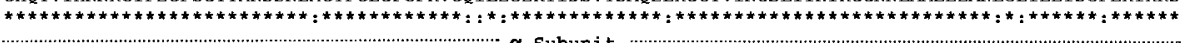

YALVSLSFFRKLRLIRGETLE IGNYSFYALDNQNLRQLWDWSKHNLTISQGKLFFHYNPKLCLSEIHKMEEVSGTKGRQERNDIALKTNGDQASCENELL 473 YALVSLSEFRKLRLIRGETLE IGNYSFYALDNQNLRQLWDWSKHNLTITQGKLFFHYNPKLCLSEIHKMEEVSGTKGRQERNDIALKTNGDQASCENELL 500 YALVB. KFSS IRTTFDKILLRWEPYWF PDFRDLLGFML FYKEAPYQNVTEFDGQDACGSNSWTVVDIDPPLRSNDPKAQN - - HPGWLMRGLKPWTQYAIFVKTLVT 571

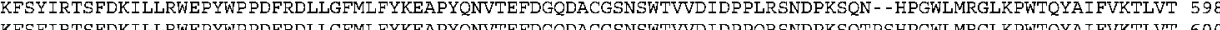
KFSFIRTSFDKILLRWEPYWP PDRDLLGFML FYKEAPYQNVTEFDGQDACGSNSWTVDIDPPQRSNDPKSQTPSHPGWLMRGLKPWTQYAIFVKTLVT 599

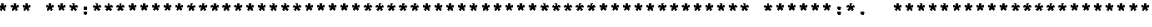

FSDERRTYGAQSDIIYVQTDATNPSVPLDPI SVSNSSSQILLKWKP PSDPNGNITHYLVFFWERPEEDRELYKELDYCLKGLKLFSRTWSPPFESDDSOKHN 671 FSDERRTYGAKSDI IYVQTDATNPSVPLDPISVSNSSSQIILKWKPPSDPNGNITHYLVFWERQAEDSELFELDYCLKGLKLFSRTWSPPFESEDSQKHN 698 FSDERRTYGAKSDITYVQTDATNESVPLDPISVSNSSSQIILKWKK FSDERRTYGAKSDI IYVQTDATNPSVPLDPISVSNSSSQIILKWKPPSDPNGNITHYLVYWERQAEDSELFELDYCLKGLKLFSRTWSPPFESDDSQKHN 699 Proteolytic cleavage site

QSEYEDSAGECCSCPKTDSQILKEVEESSFRKTFEDYLHNVVFV QSEYEDSAGECCSCPKTDSOI LKEVEESSFRKTFEDYLHNVVFVP- - -1, RPSRKRRSLGEVNNVTAAAPTVPGFSNT"TSTSVPVSPEVHRPF 759 QSEXDSASECCSCPKTDSQILKELEESSFRKTFEDYLHNVVFV- - - - - - - RPSRKRRSLEEVGNVTATTLTLPDFPNVSSTIVPTSPE ERPF 786

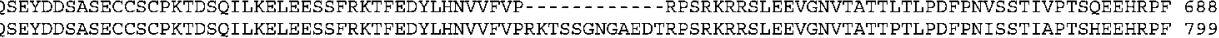
a

EKVWNKESLVISGLRHFTGYRIELQACNQDTPEERCSVAAYVSARTMPEAKADDIVGFVTHEIFENNVVHLMWOEPKDPNGLIVLYEVSYRRYGDEELHL 859 EKVVNKESLVISGLRHF"TGYRIELQACNQDTPEERCSVAAYVSARTMPEAKADDIVGPVTHEIFENNVVHLMWQEPKEPNGLIVLYEVSYRRYGDEETHL 886 EKVVNKESLVISGLRHFTGYR IELQACNQDSPDERCSVAAYVSARTMPEAKADDIVGFVTHEIFENNVVHLMWQEPKEPNGLIVLYEVSYRRYGDEELHL 888 EKVVNKESLVISGLRHFTGYR IELQACNQDSPEERSGVAAYVSARTMPEAKADDIVGPVTHEI FENNVVHLMWQEPKEPNGLIVLYEVSYRRYGDEELHL 899

CVSRKHFALERGCRLRGLSPGNYSVRVRATSLAGNGSWTEATYPYVTDY-HVPSNIAKIIIGPLIFVEDPSVVIGS YYLFLRKKOFDGPLGELYASSNPE 958 WE CVSRKHFALERGCRLRGLSPGNYSVRVRATSLAGNGSWTEPTY FYVTDYIDVPSNI AKI I I GPLIFVFLFSVVIGS IYLFLRKRQPDGPMGPLYASSNPE 988 CVSRKHFALERGCRLRGLSPGNYSVRVRATSLAGNGSWTEPTYFYVTDYLDVPSNIAKIIIGPLIFVELFSVVIGSIYLFLRKROPDGPMGPLYA.SSNPE 999

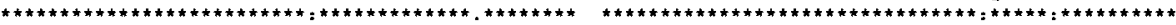

\section{B-Subunit}

YLSA.SDVFPCSVYVPDEWEVPREKIALLRELGQGSEGMVYEGNAKDI IKGEAETRVAVKTVNESASLRERIEFLNEASVMKGFTCHHVVRLLGVVSKGQF 1058

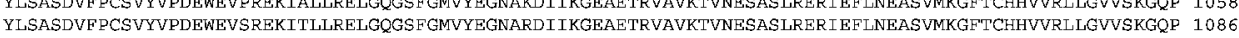

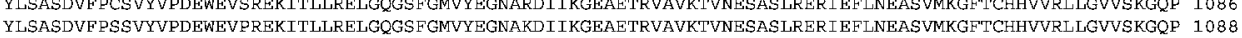
YLSASDVFPSSVYVPDEWEVPREKITLLRELGQGSFGMVYEGNAKDI I KGEVETRVAVKTVNESASLRERIEFLNEASVMKGFTCHHVVRLLGVVSKGOF 1099

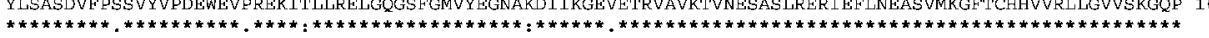

TLVVMELMAHGDLKSYLRSLR PEAENNPGRPPPTFQEM I QMAAE IADGMAYLNAKKFVHRDLAARNCMVAHDETVKIGDFGMTRD Y:EAIYY YRKGGKGLL 1158

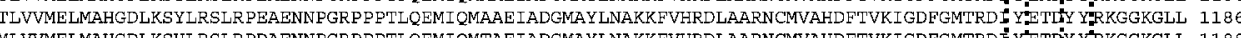
MLWMELMAGDLKSHLRSLR DA.

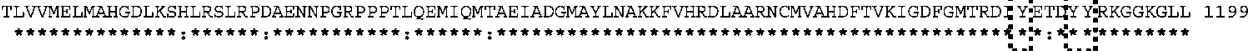

PVRWMAPESLKDGVFTISSDMWSFGVLWEITSLAEOPYOGLSNEOVLKFVMDGGYLDQPDNCPERVTDLMRMCWQFNPKMRFTFLEIVSLIKDDLHPSF 1218 PVRWMAPESLKDGVFTTSSDMWSFGVVLEEITSLAAQPYQGLSNEQVLKFVMDGGYLDQPDNCPERVTDLMRMCWQFNPNMR FTFLEIVNLLKDDLHPSF 1246 PVRWMSPESLKDGVFTASSDMWSFGVVLWEITSLAEQPYQGLSNEQVLKFVMDGGYLDPPDNCPERLTDLMRMCWQFNPKMRFTFLEIVNLLKDDLHPSF 1248 PVRWMSPESLKDGVFTASSDMWSFGVVLEITSLAEQPYQGLSNEQVLKFVMDGGYLDPPDNCPERLTDLMRMCWOFNPKMRFTFLEIVNLLKDDLHPSF 1259

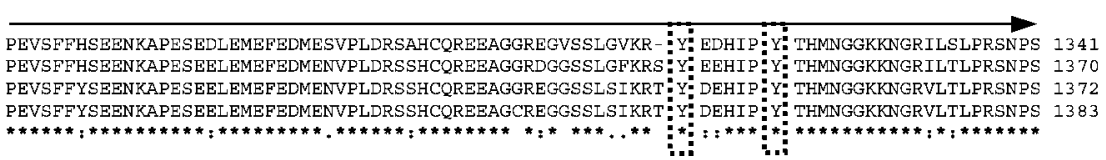

Figure 2 Deduced amino acid sequence of rabIR cDNA. The single open reading frame of rabIR cDNA is translated into a 1341 amino acid protein. Interspecies comparisons of the rabbit IR protein sequence show that the rabbit cDNA and protein sequences belong to the IR family. The multiple sequence alignments of rabbit IR protein with mouse, rat, rabbit and human (accession number X02160) sequences were performed by CLUSTAL W (1.82) multiple sequence alignment. The regions for the signal peptide, the $\alpha$ - and $\beta$-subunit and the proteolytic cleavage site are marked with lines and arrows. The consensus is displayed by the following symbols denoting the degree of conservation observed in each column: (*) means that the residues or nucleotides in that column are identical in all sequences in the alignment, (:) means that conserved substitutions have been observed, (.) means that semi-conserved substitutions have occurred. IR amino acids found to be involved in insulin binding are underlined in the rabbit sequence. Conserved tyrosine residues for autophosphorylation are framed in boxes in the $\beta$-subunit. INSR, insulin receptor. 
Table 2 Homology of rabbit GLUT4 with GLUT4 of four other mammalian species and of rabbit IR with IR of three other mammalian species.

\begin{tabular}{|c|c|c|c|c|c|c|}
\hline \multirow[b]{2}{*}{ Species } & \multicolumn{3}{|c|}{ cDNA } & \multicolumn{3}{|c|}{ Protein } \\
\hline & $\begin{array}{l}\text { Accession } \\
\text { number }\end{array}$ & $\begin{array}{l}\text { Identity (identical } \\
\text { bases/abs. number) }\end{array}$ & $\begin{array}{l}\text { Identity } \\
(\%)\end{array}$ & $\begin{array}{l}\text { Accession } \\
\text { number }\end{array}$ & $\begin{array}{l}\text { Identity (identical } \\
\text { aa/abs. number) }\end{array}$ & $\begin{array}{l}\text { Identity } \\
(\%)\end{array}$ \\
\hline Homo sapiens GLUT4 & M91463 & $1424 / 1549$ & 91 & M20747 & $494 / 509$ & 97 \\
\hline Equus caballus GLUT4 & AF531753 & $1394 / 1531$ & 91 & AF531753 & $492 / 509$ & 96 \\
\hline Mus musculus GLUT4 & AB008453 & $1341 / 1531$ & 87 & AB008453 & $490 / 509$ & 96 \\
\hline Rattus norvegicus GLUT4 & X14771 & 1339/1531 & 87 & D28561 & $491 / 509$ & 96 \\
\hline Homo sapiens IR & X02160.1 & $3595 / 4031$ & 89 & X02160 & $1287 / 1343$ & 95 \\
\hline Rattus norvegicus IR & NM01701.1 & $1852 / 2144$ & 86 & NM010658 & $1260 / 1345$ & 93 \\
\hline Mus musculus IR & NM105681.1 & $1855 / 2156$ & 85 & NM017071 & $1256 / 1357$ & 92 \\
\hline
\end{tabular}

aa, amino acids, abs., absolute (total).

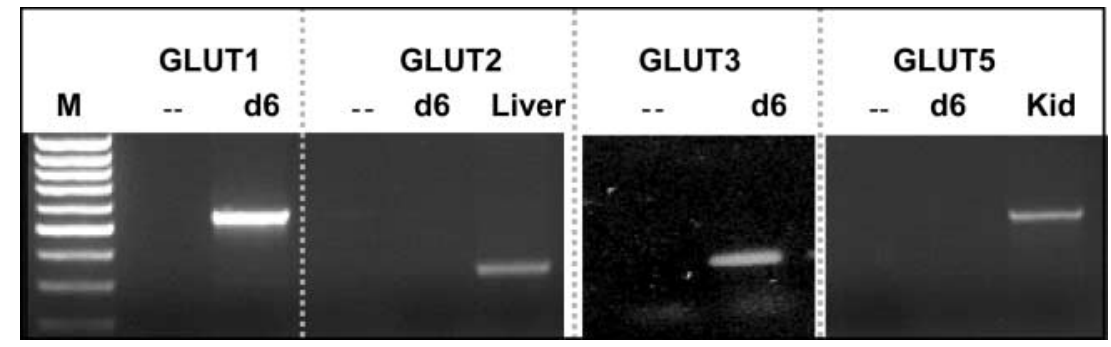

Figure 3 Messenger RNA of GLUT1, 2, 3 and 5 in expanded rabbit blastocysts. The total RNA from 10 pooled 6-day-old (d6) rabbit blastocysts was reverse transcribed and amplified with specific primers for glucose transporter 1 (GLUT1, $517 \mathrm{bp}$ ), glucose transporter 2 (GLUT2, $323 \mathrm{bp}$ ), glucose transporter 3 (GLUT3, $367 \mathrm{bp}$ ) and glucose transporter 5 (GLUT5, $523 \mathrm{bp)}$ ). Resulting PCR fragments were resolved in $1.8 \%$ agarose gel. In case of GLUT2 and GLUT5 the PCR conditions were controlled on rabbit liver (Liver) or kidney (Kid) cDNA as positive controls. For each primer combination a PCR control without cDNA template (- -) was performed.

reasonable to speculate, however, that the rabbit blastocyst does express the full complement of the IR-GLUT signal cascade. Since morulae do transcribe these genes or only in low copy numbers, the expression of IR signaling components seems to be under developmental control. The function and developmental impact of this cascade, for example its involvement in the mitogenic activity and/or energy metabolism of blastocysts, still needs to be uncovered.

Sequence analyses of the new rabbit genes prove that the rabIR encoded protein is a member of the IR family and that rabGLUT4 and 8 belong to the facilitative glucose transporters. The amino acid sequence responsible for insulin binding is almost identical with the human insulin receptor sequence. Insulin initiates its effects through interaction with the high-affinity cell surface glycoprotein receptors, consisting of two $\alpha(135 \mathrm{kDa})$ and two $\beta$ (95 kDa) subunits each. The human insulin receptor is expressed in two isoforms, A and B, which are generated by alternate splicing (Ebina et al. 1985, Ullrich et al. 1985, Seino \& Bell 1989). The two mature receptor proteins differ in the absence or presence of 12 aa in the $\mathrm{C}$ terminus of the extracellular $\alpha$ subunit. This insertion is encoded by the 36 nucleotide exon 11 of the receptor gene (Seino et al. 1989). The A and B isoforms have different tissue distributions (Moller et al. 1989, Seino \& Bell 1989) and functional properties (Yamaguchi et al. 1991, 1993, Kosaki et al. 1995). The $\alpha$ subunit in the rab IR was found to be highly homologous with the $\alpha$ subunits of human IR isoform A without insertion of exon 11. A more detailed analysis regarding the presence of two IR isoforms in rabbit tissues was not performed in the present study.

The IR protein-tyrosine kinase has been implicated as the mediator of most, if not all, effects of insulin. IR deficiency in IR $\mathrm{R}^{-1-}$ mice caused a number of major metabolic alterations and led to the death of the newborns within one week after birth (Accili et al. 1996). At birth, mouse $\mathbb{I R}^{-/-}$mutant pups could not be distinguished from other littermates, contrary to human patients with mutations in IR, which usually have a severe intrauterine growth retardation (Lamothe et al. 1998).

During embryo development insulin exerts a number of important actions. (i) It accelerates the uptake of amino acids and proteins by preimplantation embryos (mouse: Dunglison \& Kaye 1993; pig: Lewis et al. 1992), (ii) it promotes blastocyst formation and increases the number of embryonic cells (Matsui et al. 1995, Herrler et al. 1998, Augustin et al. 2003), in some species specifically of ICM cells (mouse: Harvey \& Kaye 1990, Gardner \& Kaye 1991, Smith et al. 1993, bovine: Sirisathien et al. 2003), and (iii) it prevents apoptosis (rabbit: Herrler et al. 1998, bovine: Augustin et al. 2003). The mechanism of insulin action in mammalian embryos is still unclear. Also, the effects on glucose transport and metabolism need further consideration. For mouse blastocysts it has been shown that insulin 
A)

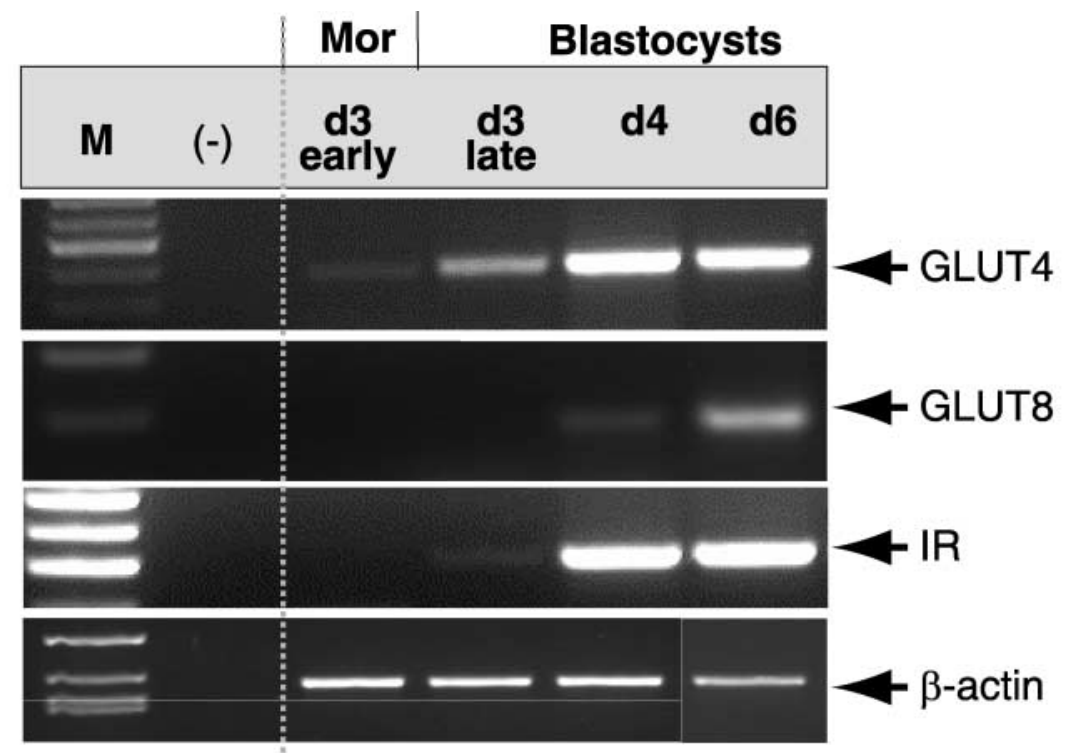

B)

C)

D)
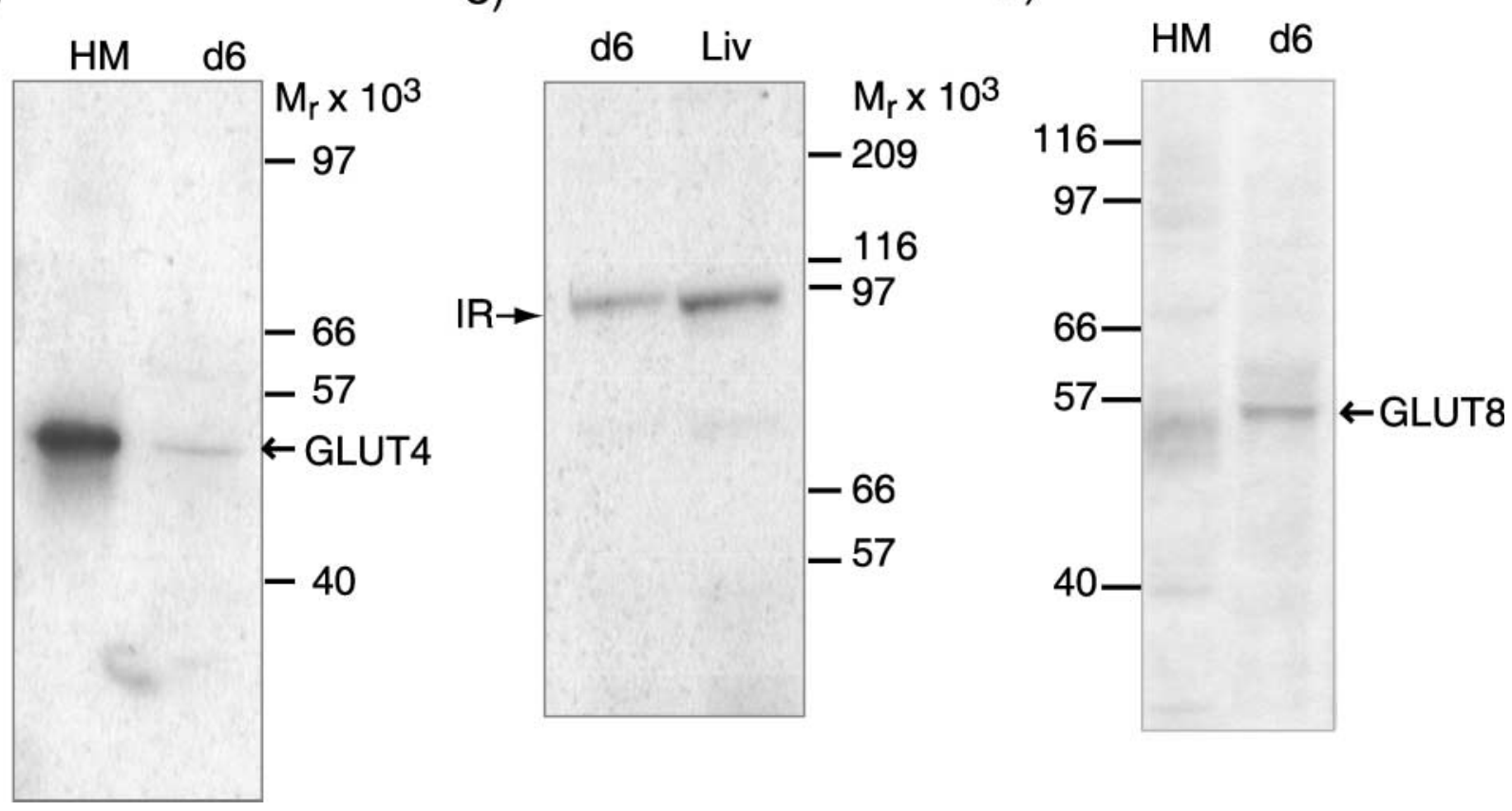

Figure 4 Messenger RNA and protein expression of GLUT4, GLUT8 and IR in rabbit preimplantation embryos. For RT-PCR (A) total RNA from 25 early day-3 morulae ( $\mathrm{d} 3$ early), 15 day-3 late ( $\mathrm{d} 3$ late), 15 day-4 (d4) and 5 day- 6 blastocysts ( $\mathrm{d} 6$ ) were reverse transcribed and amplified with specific rabbit primers for glucose transporter 4 (GLUT4, 398 bp), glucose transporter 8 (GLUT8, 170 bp), insulin receptor (IR, 497 bp) and $\beta$-actin (450 bp). The protein expression was analyzed by Western blotting in (B) (C) and (D) for GLUT4, IR and GLUT8 respectively. Total protein amount of 10 pooled rabbit day- 6 blastocysts was isolated and $20 \mu \mathrm{g}$ protein were resolved on $8 \%$ SDS-PAGE and immunoblotted with anti-GLUT4 (B), anti- $\beta$-subunit IR (C) and anti-GLUT8 (D). As controls for GLUT4, GLUT8 and IR protein, $40 \mu \mathrm{g}$ total protein extracts of heart muscle (HM in B, D) and liver (Liv in $\mathrm{C}$ ) were added to the blot.

and IGF-I act via IR to increase glucose uptake (Gardner \& Leese 1988, Harvey \& Kaye 1991, Pantaleon \& Kaye 1996, Carayannopoulos et al. 2000). Compared with IGF-I, glucose uptake, measured by uptake of 3-o-methylD-glucose, was clearly more stimulated by the IGF-IR/ IGF-I system than by insulin (Pantaleon \& Kaye 1996).
An insulin-dependent increase in glucose uptake via translocation of GLUT4, as described for differentiated myocytes and adipocytes, has not yet been shown in preimplantation embryos. First screening studies of glucose transporter isoform expression in mammalian preimplantation embryos, performed in mice, failed to prove 


\section{A)}

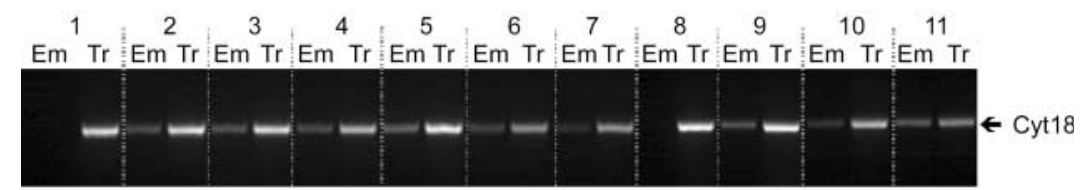

B)

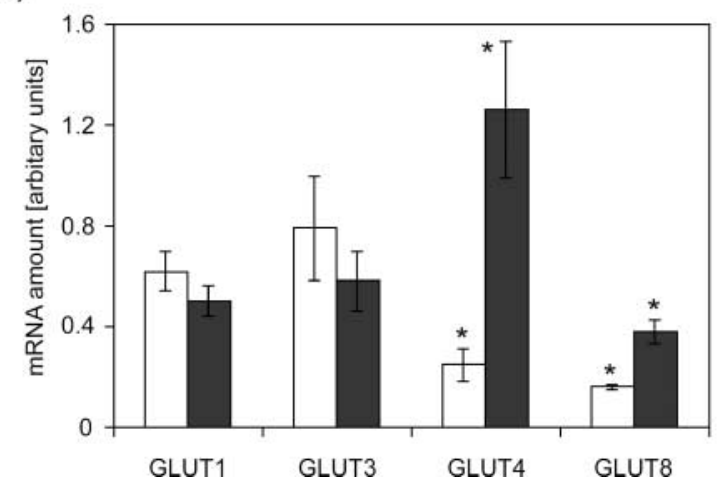

Figure 5 Relative amounts of GLUT1, GLUT3, GLUT4 and GLUT8 mRNA in the trophoblast and embryoblast of rabbit blastocysts. (A) The relative amounts of GLUT1, 3, 4 and 8 transcripts were quantified by semiquantitative RT-PCR in isolated trophoblast (Tr) and embryoblast (Em) of 11 day- $6(\mathrm{~d} 6)$ blastocysts $(1-11)$ as described in Materials and Methods. The housekeeping gene, $\beta$-actin, was used as an internal standard. The tissue separation was controlled by PCR amplification of cytokeratin 18 (cyt 18) as a specific trophoblast marker. In all studied individuals, cytokeratin 18 mRNA was clearly higher in trophoblast than in embryoblast cells, proving the stable and reliable separation of both cell lineages. (B) The expression of GLUT4 and GLUT8 mRNA was significantly higher in the trophoblast (solid bars) than in the embryoblast (open bars; $\left.{ }^{*} P<0.05\right)$, while no cell-lineage effects were found for GLUT1 and GLUT3.

GLUT4 expression (Hogan et al. 1991, Aghayan et al. 1992). The expression of the insulin responsive GLUT4 isoform has been shown for the first time in bovine blastocysts (Navarrete Santos et al. 2000). During bovine preimplantation development GLUT4 was expressed in 8-dayold in vitro-derived blastocysts and in day 14 elongated in vivo-grown blastocysts (Augustin et al. 2001). Another isoform demonstrated to be insulin responsive in blastocysts, GLUT8, has recently been described in mouse blastocysts (Carayannopoulos et al. 2000). GLUT8 was found to change its intracellular localization and to be involved in increased glucose uptake after insulin treatment in murine blastocysts (Carayannopoulos et al. 2000). Inhibition of GLUT8 translation and translocation enhanced the rate of apoptosis in mouse blastocysts (Pinto et al. 2002). Functional studies in other species expressing this isoform (bovine, rabbit) are needed to clarify the exact role of GLUT8 for embryo development. It is remarkable and may be indicative of different functions of GLUT isoforms in different species that mice and rabbits express GLUT8 only at the blastocyst stage (Carayannopoulos et al. 2000, present study) while during bovine embryogenesis GLUT8 mRNA is present from oocytes throughout preimplantation development (Augustin et al. 2001).

In mouse blastocysts, the high affinity isoform 3, localized in the outer apical cell membrane of the trophoblast cells, mediates glucose transport from the uterine fluid into the blastocyst (Pantaleon et al. 1997). GLUT1, situated at the basal and basolateral trophoblast cell membranes, accomplishes the supply of the ICM (Pantaleon \&
Kaye 1998). In the present study, both isoforms were also found in the rabbit, pointing to a similar mechanism for glucose uptake and supply as in mice. The experimental proof for GLUT2 expression in mammalian preimplantation embryos is controversial. Transcripts were reported for mice 8-cell/compacted morulae (Schultz et al. 1992) and blastocysts (Harvey \& Kaye 1991). The protein was found in blastocysts (Aghayan et al. 1992). However, in the present study, as in others (mouse: Morita et al. 1992, Tonack et al. 2004, cattle: Augustin et al. 2001), GLUT2 expression could not be verified in rabbit blastocysts.

The diversity of glucose transporter expression in mammalian embryos presumably reflects the importance of glucose as the major metabolic energy substrate. Diverse glucose transporters have evolved to allow an efficient, stage- and cell-specific uptake and utilization. Glucose concentration in human serum is maintained around 5 (4.4 to 6.6) $\mathrm{mM}$. The early human embryo is exposed to lower (3.15 mM; Gardner et al. 1996) or almost the same (Casslen \& Nilsson 1984) glucose concentrations in utero as those present in serum. The oxygen level in this organ, however, is significantly lower than in blood (Fischer \& Bavister 1993). This specific constellation and its physiological implications may have led to the more complex furnishing with glucose transporters in embryos than in differentiated muscle, fat or neuronal cells. Considering glucose uptake by preimplantation embryos, which is in a pmol per embryo per hour range (rabbit: Robinson et al. 1990, rat: Brison \& Leese 1994, mouse: Martin \& Leese 1999, bovine: Donnay \& Leese 1999), and assuming a 

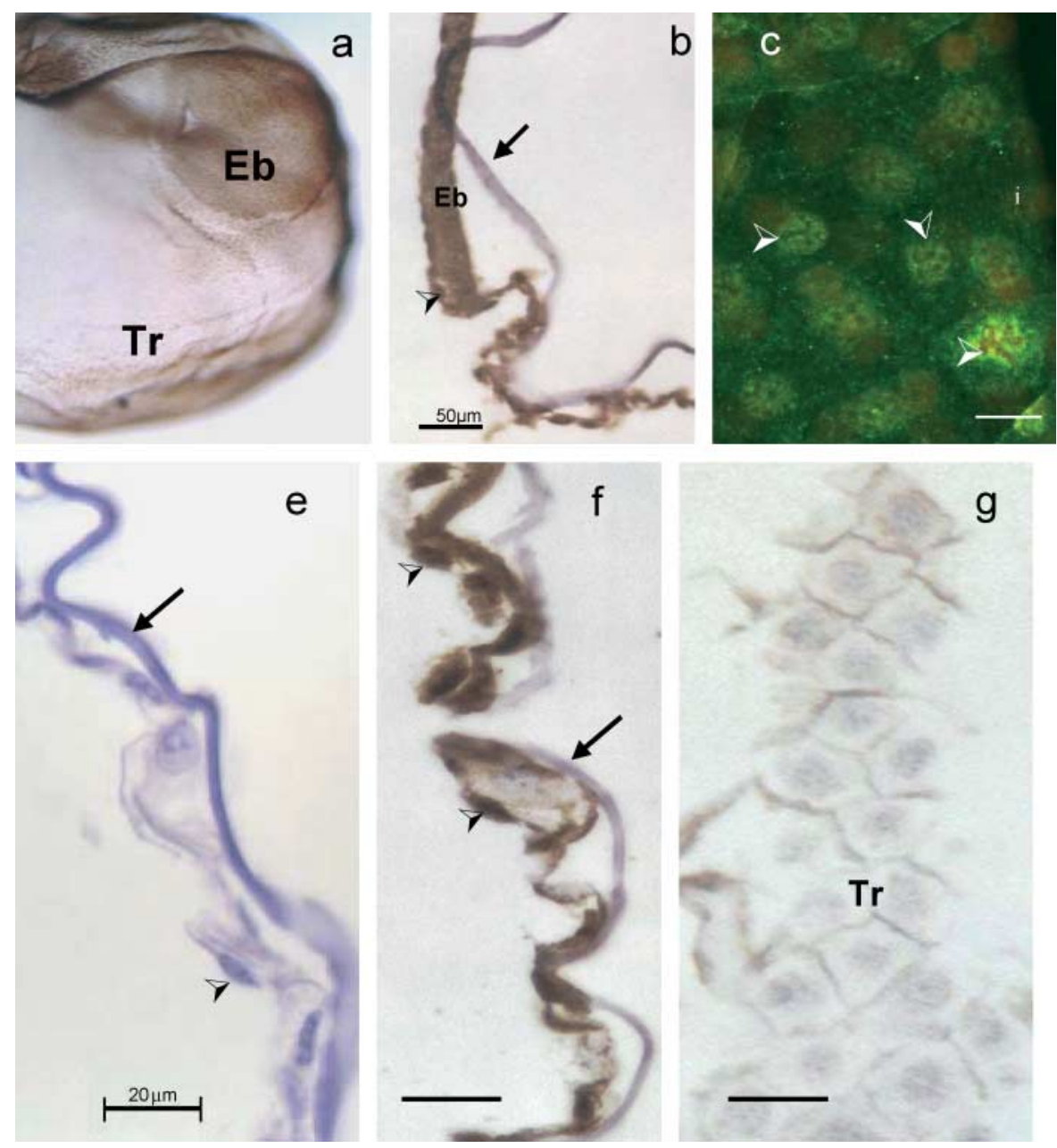

Figure 6 Localization of GLUT4 in day-6 (d6) blastocysts. Whole mount IHC (a) of a 6-day-old blastocyst shows positive staining for GLUT4 in embryoblast (Eb) and trophoblast (Tr) cells. The GLUT4 protein was visualized by peroxidase-DAB reaction (brown color in a, b, $\mathrm{f}$, g). The nuclei were counterstained with hematoxylin $(\mathrm{e}, \mathrm{f}, \mathrm{g})$. The subcellular localization was investigated by conventional light microscopy on paraffin sections (b, e, f, g) and whole mount confocal microscopy (c) with a fluorescence detection for GLUT4 (green color) and nuclear counterstaining with 7-aminoactinomycin (in red, c). The embryoblast cells (Eb) revealed an intense cytoplasmic staining for GLUT4 (b), whereas the outer trophoblast layer $(\mathrm{Tr})$ was stained in the cytoplasm $(\mathrm{f})$ and cell membranes $(\mathrm{g})$. The extraembryonic endoderm cells show an intense cytoplasmic and perinuclear staining $(\mathrm{e}, \mathrm{f})$. Nuclei are marked with an arrowhead in b, c, (embryoblast cells) and e, $\mathrm{f}$ (extraembryonic endoderm cells). The neozona is marked with an arrow. The bar in $(b)=50 \mu \mathrm{m}$, and bars in c, d, e, f and $g=20 \mu \mathrm{m}$.

relatively constant replenishment of intraluminal glucose stores by fresh transudates, then a sufficient supply of this nutrient can be postulated under physiological conditions in utero, even for multiovulatory species ( $\mathrm{H}$ J Leese, personal communication).

Different results have been reported on the developmental implications of an altered glucose supply for embryos. In mice, glucose deprivation affected trophoblast cells more than the ICM. In deprived blastocysts cell numbers in the trophoblast, but not in the ICM, were statistically significantly decreased (Leppens-Luisier et al. 2001). Also high glucose concentrations are reported to exert detrimental effects on embryo development. Blastocysts from diabetic rats showed an impaired growth of both cell types with cell numbers being more affected in the ICM than in the trophoblast (Dufrasnes et al. 1993). Blastocysts from diabetic mice have lower intraembryonic glucose concentrations (Moley et al. 1998) and an increase in the rate of apoptosis (Chi et al. 2000).

GLUT4 has been localized in the cytoplasm of trophoblast, embryoblast and extraembryonic endoderm cells in close association with membranes and nuclei. A GLUT4 shuttling is well investigated in insulin responsive adipocytes and myocytes (for review see Zorzano et al. 1998, Watson \& Pessin 2001). In these cells GLUT4 is associated with cytoplasmic vesicles (so-called GLUT4 storage vesicles, GSV; Rea \& James 1997) in several morphologically distinct localizations. Ultrastuctural studies have shown that GLUT4 is present in tubulovesicular structures distinct from lysosomes. As in rabbit blastocysts in the present study, GLUT4 has also been found in the perinuclear compartment which is in close vicinity to the trans-Golgi network (Hudson et al. 1992, Jhun et al. 1992, Lee et al. 1999). Insulin increases the rate of GLUT4 translocation 
from the cytoplasm to the cell membrane so that the proportion of GLUT4 at the cell surface increases from $<10 \%$ in the absence of insulin to 35 to $50 \%$ in its presence (adipocytes: Bogan et al. 2001). In the rabbit blastocyst, the cells in the outer trophoblast layer showed a comparable subcellular localization of GLUT4 as insulin sensitive tissues. The membrane localization of GLUT4 in trophoblast cells can be regarded as good evidence that the transporter is active in rabbit blastocysts. The more intense staining of the embryoblast and the extraembryonic endoderm may indicate another functional state or a different function of GLUT4. The perinuclear localization and the association of GLUT4 with the nuclear membranes, not described in adult tissues so far, support the view of a function of GLUT4 other than glucose transport in embryonic cells. Recently, a nuclear localization has been described for GLUT1 in mouse oocytes and early cleavage stages (Pantaleon et al. 2001) stressing the need for a more detailed analysis of potential functions of the various glucose transporter isoforms during early embryogenesis.

\section{Acknowledgements}

This work was supported, in part, by a grant from the Deutsche Forschungsgemeinschaft (grant FI 306/10-1).

\section{References}

Accili D, Drago J, Lee EJ, Johnson MD, Cool MH, Salvatore P, Asico LD, Jose PA, Taylor SI \& Westphal H 1996 Early neonatal death in mice homozygous for a null allele of the insulin receptor gene. Nature Genetics 12 106-109.

Aghayan M, Rao LV, Smith RM, Jarett L, Charron MJ, Thorens B \& Heyner S 1992 Development expression and cellular localization of glucose transporter molecules during mouse preimplantation development. Development 115 305-312.

Augustin R, Pocar P, Navarrete Santos A, Wrenzycki C, Gandolfi F, Niemann H \& Fischer B 2001 Glucose transporter expression is developmentally regulated in in vitro derived bovine preimplantation embryos. Molecular Reproduction and Development 60 370-376.

Augustin R, Pocar P, Wrenzycki C, Niemann H \& Fischer B 2003 Mitogenic and anti-apoptotic activity of insulin on bovine embryos produced in vitro. Reproduction 126 91-99.

Bogan JS, McKee AE \& Lodish HF 2001 Insulin-responsive compartments containing GLUT4 in 3T3-L1 and CHO cells: regulation by amino acid concentrations. Molecular and Cellular Biology 21 4785-4806.

Brison DR \& Leese HJ 1994 Blastocoel cavity formation by preimplantation rat embryos in the presence of cyanide and other inhibitors of oxidative phosphorylation. Journal of Reproduction and Fertility 101 305-309.

Carayannopoulos MO, Chi MM-Y, Cui Y, Pingsterhaus JM, McKnight RA, Mueckler M, Devaskar SU \& Moley KH 2000 GLUT8 is a glucose transporter responsible for insulin-stimulated glucose uptake in the blastocyst. PNAS 97 7313-7318.

Casslen B \& Nilsson B 1984 Human uterine fluid, examined in undiluted samples for osmolarity and the concentrations of inorganic ions, albumin, glucose, and urea. American Journal of Obstetrics and Gynecology 150 877-881.

Chi MM, Manchester JK, Basuray R, Mahendra S, Strickler RC, McDougal DB Jr \& Lowry OH 1993 An unusual active hexose transport system in human and mouse preimplantation embryos. PNAS 90 10023-10025.

Chi MM-Y, Schlein AL \& Moley KH 2000 High insulin-like growth factor 1 (IGF-1) and insulin concentrations trigger apoptosis in the mouse blastocyst via down-regulation of the IGF-1 receptor. Endocrinology 141 4784-4792.

Chomczynski P \& Sacchi N 1987 Single-step method of RNA isolation by acid guanidinium thiocyanate-phenol-chloroform extraction. Analytical Biochemistry 162 156-159.

Cope DL, Holman GD, Baldwin SA \& Wolstenholme AJ 1994 Domain assembly of the GLUT1 glucose transporter. Biochemical Journal 300 291-294.

Czech MP \& Corvera S 1999 Signaling mechanisms that regulate glucose transport. Journal of Biological Chemistry $27 \mathbf{4}$ 1865-1868.

Dan-Goor M, Sasson S, Davarashvili A \& Almagor M 1997 Expression of glucose transporter and glucose uptake in human oocytes and preimplantation embryos. Human Reproduction 12 $2508-2510$.

Donnay I \& Leese HJ 1999 Embryo metabolism during the expansion of the bovine blastocyst. Molecular Reproduction and Development 53 171-178.

Dufrasnes E, Vanderheyden I, Robin D, Delcourt J, Pampfer S \& De Hertogh R 1993 Glucose and pyruvate metabolism in preimplantation blastocysts from normal and diabetic rats. Journal of Reproduction and Fertility 98 169-177.

Dunglison GF \& Kaye PL 1993 Insulin regulates protein metabolism in mouse blastocysts. Molecular Reproduction and Development $3642-48$.

Ebina $\mathbf{Y}$, Ellis L, Jarnagin K, Edery $\mathrm{M}$, Graf L, Clauser E, Ou JH, Masiarz F, Kan YW, Goldfine ID, Roth RA \& Rutter WJ 1985 The human insulin receptor CDNA: the structural basis for hormoneactivated transmembrane signalling. Cell 40 747-758.

Fischer B \& Bavister BD 1993 Oxygen tension in the mammalian female genital tract. Journal of Reproduction and Fertility 99 673-679.

Gardner DK \& Leese HJ 1988 The role of glucose and pyruvate transport in regulating nutrient utilization by preimplantation mouse embryo. Development 104 423-429.

Gardner HG \& Kaye PL 1991 Insulin increases cell numbers and morphological development in mouse preimplantation embryos in vitro. Reproduction, Fertility, and Development 3 79-91.

Gardner DK, Lane M, Calderon I \& Leeton J 1996 Environment of the preimplantation human embryo in vivo: metabolite analysis of oviduct and uterine fluids and metabolism of cumulus cells. Fertility and Sterility 66 670-671.

Harvey MB \& Kaye PL 1988 Insulin stimulates protein synthesis in compacted mouse embryos. Endocrinology 122 1182-1184.

Harvey MB \& Kaye PL 1990 Insulin increases the cell number of the inner cell mass and stimulates morphological development of mouse blastocysts in vitro. Development 110 963-967.

Harvey MB \& Kaye PL 1991 Mouse blastocysts respond metabolically to short-term stimulation by insulin and IGF-I through the insulin receptor. Molecular Reproduction and Development 29 $253-258$.

Herrler A, Krusche CA \& Beier HM 1998 Insulin and insulin-like growth factor-I promote rabbit blastocyst development and prevent apoptosis. Biology of Reproduction 59 1302-1310.

Heyner S, Rao LV, Jarett L \& Smith RM 1989 Preimplantation mouse embryos internalize maternal insulin via receptor-mediated endocytosis: pattern of uptake and functional correlations. Developmental Biology 134 48-58.

Hogan A, Heyner S, Charron MJ, Copeland NG, Gilbert DJ, Jenkins NA, Thorens B \& Schultz GA 1991 Glucose transporter gene expression in early mouse embryos. Development 113 363-372.

Hudson AW, Ruiz M \& Birnbaum MJ 1992 Isoform-specific subcellular targeting of glucose transporters in mouse fibroblasts. Journal of Cell Biology 116 785-797. 
Jhun BH, Rampal AL, Liu H, Lachaal M \& Jung CY 1992 Effects of insulin on steady state kinetics of GLUT 4 subcellular distribution in rat adipocytes. Evidence of constitutive GLUT4 recycling. Journal of Biological Chemistry 267 17710-17715.

Joost HG, Bell GI, Best JD, Birnbaum MJ, Charron MJ, Chen YT, Doege H, James DE, Lodish HF, Moley KH, Moley JF, Mueckler M, Rogers S, Schurmann A, Seino S \& Thorens B 2002 Nomenclature of the GLUT/SLC2A family of sugar/polyol transport facilitators. American Journal of Physiology. Endocrinology and Metabolism 282 E974-E976.

Kaye PL 1997 Preimplantation growth factor physiology. Reviews of Reproduction 2 121-127.

Kietz S \& Fischer B 2003 Polychlorinated biphenyls affect gene expression in the rabbit preimplantation embryo. Molecular Reproduction and Development 64 251-260.

Koerber S, Santos AN, Tetens F, Kuchenhoff A \& Fischer B 1998 Increased expression of NADH-ubiquinone oxidoreductase chain 2 (ND2) in preimplantation rabbit embryos cultured with $20 \%$ oxygen concentration. Molecular Reproduction and Development 49 394-399.

Korgun ET, Demir R, Hammer A, Dohr G, Desoye G, Skofitsch G \& Hahn T 2001 Glucose transporter expression in rat embryo and uterus during decidualization, implantation, and early postimplantation. Biology of Reproduction 65 1364-1370.

Kosaki A, Pillay TS, Xu L \& Webster NJ 1995 The B isoform of the insulin receptor signals more efficiently than the $\mathrm{A}$ isoform in HepG2 cells. Journal of Biological Chemistry $27020816-20823$.

Lamothe B, Baudry A, Christoffersen CT, De Meyts P, Jami J, Bucchini D \& Joshi RL 1998 Insulin receptor-deficient cells as a new tool for dissecting complex interplay in insulin and insulin-like growth factors. FEBS Letters 426 381-385.

Lee J \& Pilch PF 1994 The insulin receptor: structure, function, and signaling. American Journal of Physiology 266 C319-C334.

Lee W, Ryu J, Souto RP, Pilch PF \& Jung CY 1999 Separation and partial characterization of three distinct intracellular GLUT4 compartments in rat adipocytes. Subcellular fractionation without homogenization. Journal of Biological Chemistry $\mathbf{2 7 4}$ 37755-37762.

Leppens-Luisier G, Urner F \& Sakkas D 2001 Facilitated glucose transporters play a crucial role throughout mouse preimplantation embryo development. Human Reproduction 16 1229-1236.

Lequarre AS, Grisart B, Moreau B, Schuurbiers N, Massip A \& Dessy F 1997 Glucose metabolism during bovine preimplantation development: analysis of gene expression in single oocytes and embryos. Molecular Reproduction and Development 48 216-226.

Lewis AM, Kaye PL, Lising R \& Cameron RD 1992 Stimulation of protein synthesis and expansion of pig blastocysts by insulin in vitro. Reproduction, Fertility, and Development 4 119-123.

Lighten AD, Hardy K \& Winston RML 1997 Expression of mRNA for the insulin-like growth factors and their receptors in human preimplantation embryos. Molecular Reproduction and Development 47 134-139.

Markham KE \& Kaye PL 2003 Growth hormone, insulin-like growth factor I and cell proliferation in the mouse blastocyst. Reproduction 125 327-336.

Martin KL \& Leese HJ 1999 Role of developmental factors in the switch from pyruvate to glucose as the major exogenous energy substrate in the preimplantation mouse embryo. Reproduction, Fertility, and Development 11 425-433.

Matsui M, Takahashi Y, Hishinuma M \& Kanagawa H 1995 Insulin and insulin-like growth factor-I (IGF-I) stimulate the development of bovine embryos fertilized in vitro. Journal of Veterinary Medical Science $\mathbf{5 7}$ 1109-1111.

Moley KH, Chi MM-Y \& Mueckler MM 1998 Maternal hyperglycemia alters glucose transport and utilization in mouse preimplantation embryos. American Journal of Physiology 275 E38-E47.

Moller DE, Yokota A, Caro JF \& Flier JS 1989 Tissue-specific expression of two alternatively spliced insulin receptor mRNAs in man. Molecular Endocrinology 3 1263-1269.
Morita Y, Tsutsumi O, Hosoya I, Taketani Y, Oka Y \& Kato T 1992 Expression and possible function of glucose transporter protein GLUT1 during preimplantation mouse development from oocytes to blastocysts. Biochemical and Biophysical Research Communications 188 8-15.

Mueckler M, Caruso C, Baldwin SA, Panico M, Blench I, Morris HR, Allard WJ, Lienhard GE \& Lodish HF 1985 Sequence and structure of a human glucose transporter. Science 229 941-945.

Navarrete Santos A, Augustin R, Lazzari G, Galli C, Sreenan J \& Fischer B 2000 The insulin-dependent glucose transporter isoform 4 is expressed in bovine blastocysts. Biochemical and Biophysical Research Communications 271 753-760.

Ottensmeyer FP, Beniac DR, Luo RZ \& Yip CC 2000 Mechanism of transmembrane signaling: insulin binding and the insulin receptor. Biochemistry 39 12103-12112.

Pantaleon M \& Kaye PL 1996 IGF-I and insulin regulate glucose transport in mouse blastocysts via IGF-I receptor. Molecular Reproduction and Development 44 71-76.

Pantaleon M \& Kaye PL 1998 Glucose transporters in preimplantation development. Reviews of Reproduction 3 77-81.

Pantaleon M, Harvey MB, Pascoe WS, James DE \& Kaye PL 1997 Glucose transporter GLUT3: ontogeny, targeting, and role in the mouse blastocyst. PNAS 94 3795-3800.

Pantaleon M, Ryan JP, Gil M \& Kaye PL 2001 An unusual subcellular localization of GLUT1 and link with metabolism in oocytes and preimplantation mouse embryos. Biology of Reproduction 64 $1247-1254$

Patki V, Buxton J, Chawla A, Lifshitz L, Fogarty K, Carrington W, Tuft R \& Corvera S 2001 Insulin action on GLUT4 traffic visualized in single 3T3-I1 adipocytes by using ultra-fast microscopy. Molecular Biology of the Cell 12 129-141.

Pessin JE, Thurmond DC, Elmendorf JS, Coker KJ \& Okada S 1999 Molecular basis of insulin-stimulated GLUT4 vesicle trafficking. Location! Location! Location! Journal of Biological Chemistry $\mathbf{2 7 4}$ 2593-2596.

Pinto AB, Carayannopoulos MO, Hoehn A, Dowd L \& Moley KH 2002 Glucose transporter 8 expression and translocation are critical for murine blastocyst survival. Biology of Reproduction $\mathbf{6 6}$ $1729-1733$.

Rappolee DA, Sturm KS, Behrendtsen O, Schultz GA, Pedersen RA \& Werb Z 1992 Insulin-like growth factor II acts through an endogenous growth pathway regulated by imprinting in early mouse embryos. Genes and Development 6 939-952.

Rea S \& James DE 1997 Moving GLUT4: the biogenesis and trafficking of GLUT4 storage vesicles. Diabetes 46 1667-1677.

Robinson DH, Smith PR \& Benos DJ 1990 Hexose transport in preimplantation rabbit blastocysts. Journal of Reproduction and Fertility 89 1-11.

Schultz GA \& Heyner S 1993 Growth factors in preimplantation mammalian embryos. Oxford Reviews of Reproductive Biology 15 $43-81$.

Schultz GA, Hogan A, Watson AJ, Smith RM \& Heyner S 1992 Insulin, insulin-like growth factors and glucose transporters: temporal patterns of gene expression in early murine and bovine embryos. Reproduction, Fertility, and Development 4 361-371.

Seino S \& Bell GI 1989 Alternative splicing of human insulin receptor messenger RNA. Biochemical and Biophysical Research Communications $159312-316$.

Seino S, Seino M, Nishi S \& Bell GI 1989 Structure of the human insulin receptor gene and characterization of its promoter. PNAS $86114-118$.

Sirisathien S, Hernandez-Fonseca HJ \& Brackett BG 2003 Influences of epidermal growth factor and insulin-like growth factor-I on bovine blastocyst development in vitro. Animal Reproduction Science 77 21-32.

Smith RM, Garside WT, Aghayan M, Shi CZ, Shah N, Jarett L \& Heyner S 1993 Mouse preimplantation embryos exhibit receptormediated binding and transcytosis of maternal insulin-like growth factor I. Biology of Reproduction 49 1-12. 
Spanos S, Becker DL, Winston RM \& Hardy K 2000 Anti-apoptotic action of insulin-like growth factor-I during human preimplantation embryo development. Biology of Reproduction 63 1413-1420.

Telford NA, Hogan A, Franz CR \& Schultz GA 1990a Expression of genes for insulin and insulin-like growth factors and receptors in early postimplantation mouse embryos and embryonal carcinoma cells. Molecular Reproduction and Development 27 81-92.

Telford NA, Watson AJ \& Schultz GA 1990b Transition from maternal to embryonic control in early mammalian development: a comparison of several species. Molecular Reproduction and Development 26 90-100.

Tonack S, Fischer B \& Navarrete Santos A 2004 Expression of the insulin-responsive glucose transporter isoform 4 in blastocysts of C57/BL6 mice. Anatomy and Embryology 208 225-230.

Ullrich A, Bell JR, Chen EY, Herrera R, Petruzzelli LM, Dull TJ, Gray A, Coussens L, Liao YC, Tsubokawa M, Mason A, Seeburg P, Grunfield C, Rosen O \& Ramchandran J 1985 Human insulin receptor and its relationship to the tyrosine kinase family of oncogenes. Nature 313 756-761.

Watson AJ, Hogan A, Hahnel A, Wiemer KE \& Schultz GA 1992 Expression of growth factor ligand and receptor genes in the preimplantation bovine embryo. Molecular Reproduction and Development 31 87-95.

Watson RT \& Pessin JE 2001 Subcellular compartmentalization and trafficking of the insulin-responsive glucose transporter, GLUT4. Experimental Cell Research 271 75-83.

Wood IS \& Trayhurn P 2003 Glucose transporters (GLUT and SGLT): expanded families of sugar transport proteins. British Journal of Nutrition 89 3-9.

Wrenzycki C, Hermann D, Carnwath JW \& Niemann H 1998 Expression of RNA from developmentally important genes in preimplantation bovine embryos produced in TCM supplemented with BSA. Journal of Reproduction and Fertility 112 387-398.

Wrenzycki C, Herrmann D \& Niemann H 2003 Timing of blastocyst expansion affects spatial messenger RNA expression patterns of genes in bovine blastocysts produced in vitro. Biology of Reproduction 68 2073-2080.

Yamaguchi Y, Flier JS, Yokota A, Benecke H, Backer JM \& Moller DE 1991 Functional properties of two naturally occurring isoforms of the human insulin receptor in Chinese hamster ovary cells. Endocrinology 129 2058-2066.

Yamaguchi Y, Flier JS, Benecke H, Ransil BJ \& Moller DE 1993 Ligand-binding properties of the two isoforms of the human insulin receptor. Endocrinology 132 1132-1138.

Yaseen MA, Wrenzycki C, Herrmann D, Carnwath JW \& Niemann H 2001 Changes in the relative abundance of mRNA transcripts for insulin-like growth factor (IGF-I and IGF-II) ligands and their receptors (IGF-IR/IGF-IIR) in preimplantation bovine embryos derived from different in vitro systems. Reproduction 122 $601-610$

Zorzano A, Sevilla L, Tomas E, Camps M, Guma A \& Palacin M 1998 Trafficking pathway of GLUT4 glucose transporters in muscle (Review). International Journal of Molecular Medicine 2 263-271.

Received 13 February 2004

First decision 24 May 2004

Revised manuscript received 30 June 2004

Accepted 9 July 2004 